\title{
DETERMINING STUDENT TEACHERS' RATES OF PLAGIARISM DURING THE DISTANCE EDUCATION AND INVESTIGATING POSSIBLE REASONS FOR PLAGIARISM
}

\author{
Dr. Huseyin BAYRAM \\ ORCID: 0000-0001-6065-8865 \\ Faculty of Education \\ Agri Ibrahim Cecen University \\ Agri, TURKEY \\ Fatih TIKMAN \\ ORCID: 0000-0002-1853-6722 \\ Faculty of Education \\ Kilis 7 Aralik University \\ Kilis, TURKEY
}

Received: 13/12/2020 Accepted: 13/04/2021

\begin{abstract}
This study examined the plagiarism rates of student teachers (hereafter students) during the distance education process and investigated the reasons for plagiarising. Qualitative dominant sequential exploratory design was used. The sample consisted of students studying at two different universities in Turkey. The study group was determined in two stages as a quantitative sample and a qualitative participant group. To select the quantitative sample, the maximum diversity sampling was used, while the criterion sampling method was utilized for the qualitative participant group. The data were collected in two stages as quantitative and qualitative in accordance with the nature of the mixed-methods research. In the first stage, the assignments prepared by students were included in the plagiarism program and their similarity rates were determined. All assignments were coded according to the names of the students who prepared them. Then, the assignments with the highest and lowest rate of plagiarism were identified. In the next stage, qualitative data were collected through semi-structured interviews conducted with the students who prepared the aforementioned assignments. The interview questions were prepared to obtain in-depth information about why they plagiarized or did not plagiarize. Content analysis was applied to analyse the data, and meaningful findings were found. The findings were collected under five headings. According to the results, those with high plagiarism stated their reasons for plagiarism as their economic and social conditions were not suitable for research. On the other hand, those with low plagiarism considered plagiarism as an action such as stealing and being unfair.
\end{abstract}

Keywords: Covid-19 outbreak, distance education, plagiarism, student teachers.

\section{INTRODUCTION}

Learning takes place by shaping the information in the mind, which was obtained as a result of experience and research processes. Scientific knowledge or everyday knowledge is acquired within the scope of these processes. All variables involved in the formation of knowledge are also the elements of this process. Scientific knowledge differs from everyday knowledge as it is formed as a result of systematic stages. The person trying to reach scientific knowledge follows certain stages and reaches the information by employing the methods 
and techniques used by the discipline containing the information in question. This is called the scientific research process. Regardless of its quality (homework, project, publication, etc.), scientific research is carried out within the scope of universal ethical rules.

Science is a pile of information. Every new knowledge is created by making use of existing knowledge (Johnstone, 1991). The researcher uses the information directly, rather than retesting the information that has been proven or accepted by all circles (Towne $\&$ Shavelson, 2002; Nelson, 1959). The researcher conducts the research on the basis of this information. While using the aforementioned information, the researcher also states the sources within the scope of scientific ethics (Pjetursson \& Lang, 2008).

The use of any information without citation is considered as a violation of scientific ethical rules. Violation of ethical rules becomes a current issue in Turkey (Keskin, 2017), which has been discussed in various countries as well (Hwang \& Young, 2016; Hwang et al., 2017; Mahmood, 2009). On the other hand, ethical rules are believed to be only valid for works prepared for publication (Armstrong, 1993). However, all activities (homework, projects, activities, etc.) carried out in educational institutions based on scientific ethics must adhere to ethical rules (Davis, 1997; Thiroux \& Krasemann, 2001). Regardless of its scope, using another one's production without crediting the source is considered unethical (George, 2010).

Plagiarism is the most common unethical behaviour in the scientific field (Anderson, 2009; Currie, 1998; LoCastro \& Masuko, 2002). Plagiarism is frequently encountered at the postgraduate level (East, 2006; Guraya \& Guraya, 2017; Pecorari, 2008), undergraduate and associate degrees (Selwyn, 2008; Sentleng \& King, 2016; Smedley et al., 2015; Smith et al., 2007), and high school level (Dant, 1986; Sisti, 2007).

Educators' commitment to ethical rules is more important than the commitment of other members of society (Haas, 2005; Lane \& Schaupp, 1989). This is because educators play a vital role in shaping the behaviors and thoughts of individuals, their contribution to social production (Kohlberg \& Mayer, 1972; Shields, 2011). In this context, while designing the programs applied in teacher training institutions, teaching competencies come to the fore (U.S. Department of Education in the US, Teacher Education, 2014; in the United Kingdom, Department for Education, Initial Teacher Training (ITT): Criteria and Supporting Advice, 2019; Ministry of National Education in Turkey, Generic Teacher Competencies, 2017).

Teacher training institutions provide teacher education. In these institutions, scientific ethical rules are taught through courses such as Legal and Ethical Issues in Education (Phoenix University, 2020), Research Methods in Education (University of Southampton, 2020), Ethics and Moral Issues in Education (Yeditepe University, 2020), Introduction to Educational Research Methods (Stockholm University, 2020), and Law and Ethics in Education (Athabascau University, 2020). The main purpose of these courses is to help teachers to learn and comply with scientific ethical rules and teach these rules to young generations (Boon, 2011; Maxwell \& Schwimmer, 2016; Warnick \& Silverman, 2011).

Ever-changing world conditions also affect scientific studies. The Covid-19 (World Health Organization, 2020) virus, which emerged in China in 2020, spread all over the world in a short time and caused a global outbreak (Bedford et al., 2020; Gates, 2020; Hellewell et al., 2020). Due to the infectious character of the disease caused by the virus (Ali, 2020), curfews have been declared from time to time in many countries (Chandrasinghe et al., 2020; Raoofi et al., 2020). Many states (Al Ahdab, 2020; Hartnett et al., 2020; Pastor, 2020; Vibha et al., 2020) have restricted or postponed activities such as meetings, congresses, symposiums, and scientific research as a precaution, or have decided to conduct them in electronic environment (Nicola et al., 2020). Thus, schools were closed, and instructional activities are carried out via the internet (Ilmiyah \& Lingerie, 2020; Sercemeli \& Kurnaz, 2020). Due to distance education, measurement-evaluation activities have been tried to be provided with techniques such as homework and projects (Sinelnikov-Murylev, 2020).

Distance education is different from face-to-face education in terms of variables such as activities and measurement-evaluation tools (Mullen, 2020). During the measurement-evaluation phase of this method, major problems may occur, and ethical rules may be violated (Sheperis et al., 2020). For example, the students can ask for help or get someone else to do the assignments. While preparing the assignments or projects, they can get information from a single or few sources. Plagiarism is one of the most common ethical 
violations in the distance education process. This situation is noticed especially in the homework prepared (Ullah et al., 2020). One of the frequently used tools to determine the plagiarism rate of assignments is Turnitin. Turnitin is a computer program that shows the similarity between scientific and published studies (Batane, 2010). Turnitin does not check whether a work uploaded to the system is plagiarized. It examines the study in the database to determine whether the article is similar or matches with one of the sources and makes the markings for review (Turnitin, 2020a).

Literature underlines three dominant aspects of plagiarism: 1-plagiarism as a moral problem, 2-plagiarism as a social development problem, and 3-plagiarism as a scientific research problem (Kaposi \& Dell, 2012). There has been an increase in studies examining plagiarism especially since the beginning of the 2000s (Adam, 2016). However, few studies investigated plagiarism (Blum 2009; Dawson and Overfield 2006; Devlin and Gray 2007; Gullifer and Tyson 2010; Power 2009; Wilkinson, 2009) from the lens of students, teachers or academicians. These studies were generally carried out with structured data collection tools such as questionnaires, without in-depth examinations (Adam, 2016). To fill this gap, this study aimed to reveal the levels of pre-service teachers' plagiarism as well as the underlying reasons of it. The present study is thought to contribute to the literature and be a source for further studies as it examines plagiarism in-depth.

\section{PURPOSE OF THE STUDY}

This study aimed to determine the plagiarism rates of student teachers during the distance education and to identify the underlying reasons. Therefore, the following questions were sought:

- What are the student teachers' general rates of plagiarism?

- What are the student teachers' rates of plagiarism according to gender?

- What are the student teachers' rates of plagiarism according to year of study?

- What are the student teachers' rates of plagiarism according to the departments they are studying?

- What are the student teachers' rates of plagiarism according to geographical regions?

- How do they perceive plagiarism?

In the current study, Turnitin similarity rates of student teachers were examined in terms of gender, year of study, department they study, and geographical region. Student teachers with high and low similarity rates were determined. Then, teachers were interviewed in order to reveal their perceptions on plagiarism.

\section{METHOD}

Mixed-methods research was used in this study. Mixed-methods research, in which quantitative and qualitative research methodologies work together, provides data diversity and multiple perspectives (Tashakkori \& Teddlie, 2003; Ivankowa \& Kawamura, 2010). Mixed-methods research varies according to the dominant method (quantitative dominant; qualitative dominant) and the priority order of the method (quantitativequalitative; qualitative-quantitative) (Creswell \& Plano-Clark, 2017; Johnson \& Onwuegbuzie, 2004). The reasons for using mixed methodologies in scientific research are to examine the event, phenomenon, or situation more comprehensively, to provide diversity in the data collection process, and to create multiple hypotheses (Creswell, 2016; Bryman, 2012; Doyle et al., 2009). This study used the mixed-methods research because of the aforementioned reasons. The researchers adopted the mixed-methods research to examine the subject in multiple ways, to create a rich data set, and to evaluate the subject from different perspectives.

\section{Design}

This study used was carried out with mixed methods sequential exploratory design. This design requires a sequential use of quantitative and qualitative methodologies (Greene, 2005). The reason for using the aforementioned design is that data collection and analysis were carried out in two stages. Studies conducted 
with mixed methods sequential exploratory design can be either qualitatively dominant or quantitatively dominant. The study purpose is the main determinant in this matter. If the study aims to identify the causes of the results, qualitative dominant is applied. If the goal is to determine definite results, quantitative dominant design is used (Morse, 1991). In this study, qualitative dominant sequential exploratory design was employed. This is because the main purpose of the current study was to reveal the underlying reasons for high and low plagiarism. Thus, quantitative data were collected and analysed to determine the plagiarism rate. To examine the underlying reasons, a qualitative participant group was formed. Figure 1 presents the use of the sequential exploratory design.

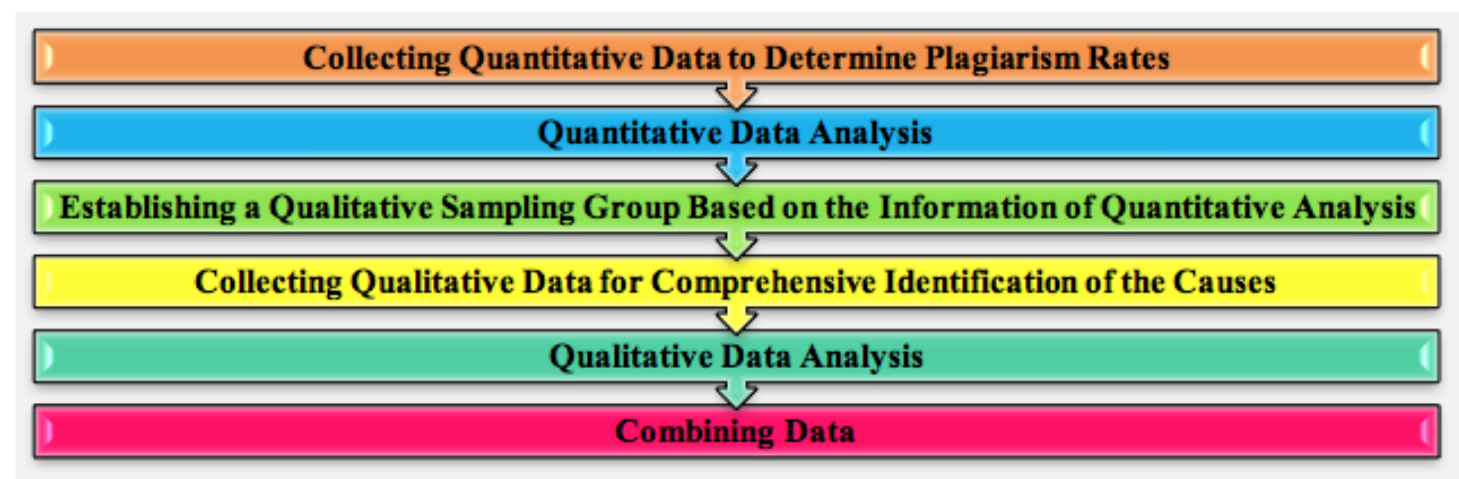

Figure 1. The stages followed in the use of the research design.

\section{Study Group}

The study group was determined as quantitative sample and qualitative participant group within the scope of the requirements of mixed methods sequential exploratory design.

\section{Quantitative Sampling}

In the first phase, quantitative sample group was formed since quantitative data were prioritized. At this stage, maximum diversity sampling was used. Maximum diversity sampling is for providing the highest level of diversity in the sample group to be selected from the study population (Byrne, 2001; Karasar, 2018). Table 1 presents demographic information of the participants.

Table 1. Demographic information of the students

\begin{tabular}{lcccccc}
\hline \multirow{2}{*}{ Department } & \multicolumn{2}{c}{ Gender } & \multicolumn{5}{c}{ Year of study } \\
& Female & Male & Total & 2nd & 3th & Total \\
\hline Pre-School Teaching & 19 & 5 & 24 & - & 24 & 24 \\
Turkish Language Teaching & 52 & 23 & 75 & 36 & 39 & 75 \\
Primary School Teaching & 53 & 37 & 90 & 53 & 37 & 90 \\
Social Sciences Teaching & 41 & 26 & 67 & 25 & 42 & 67 \\
Mathematics Teaching & 25 & 18 & 43 & 43 & - & 43 \\
Music Teaching & 9 & 8 & 17 & 17 & - & 17 \\
Art Teaching & 15 & 18 & 33 & 33 & - & 33 \\
\hline Total & $\mathbf{2 1 4}$ & $\mathbf{1 3 5}$ & $\mathbf{3 4 9}$ & $\mathbf{2 0 7}$ & $\mathbf{1 4 2}$ & $\mathbf{3 4 9}$ \\
\hline
\end{tabular}

One assignment of each student was included in the process. 
The sample consisted of students studying at various departments in two different universities in Turkey, such as pre-school teaching, Turkish language teaching, primary school teaching, social sciences teaching, mathematics teaching, music teaching, and art teaching. To provide maximum diversity, a total of 349 second and third-year students (214 females and 135 males) studying at different departments were recruited.

\section{Qualitative Participant Group}

In the second phase, criterion sampling was used to determine the group from which qualitative data will be collected. Criterion sampling involves selecting participants that meet some predetermined criterion of importance (Coyne, 1997; Yildirim \& Simsek, 2016). The criteria taken into account when creating the qualitative participant group were as follows: choosing an equal number of participants from both universities, determining the ones who made the most and the least plagiarism, and having close numbers of females and males. In this context, 10 participants (5 from each university) were selected.

\section{Data Collection and Analysis}

Data were collected in two stages as quantitative and qualitative.

\section{Quantitative Data Collection and Analysis}

The first step of the data collection process was to examine the assignments of the students. Among these assignments, those suitable for citing references and quoting (which are suitable for plagiarism) were determined. These assignments are also related to collect information from the literature. Homework was checked by 5 experts, and the qualifiable ones were included in the study. Then, the similarity percentages of these assignments were examined via the Turnitin program. Besides, the lower percentage of similarity (acceptable percentage) was determined. While determining the lower limit of similarity, the average of the lower limit of similarity of some universities in Turkey was considered. Table 2 shows the lower limits. Turkey's geographical regions were considered while choosing universities.

Table 2. The Lower Limit of Similarity Determined by Some Universities/ Institutes in Turkey

\begin{tabular}{clc}
\hline & Universities/ Institutes & Similarity \\
\hline 1 & Ankara University Institute of Educational Sciences & below $10 \%$ \\
2 & Dokuz Eylul University Institute of Educational Sciences & below $15 \%$ \\
3 & Ege University Institute of Health Sciences & below $15 \%$ \\
4 & Agri lbrahim Cecen University Journal of the Institute of Social Sciences & below 20\% \\
5 & Ankara Haci Bayram Veli University & below 20\% \\
6 & Gazi University Institute of Educational Sciences & below 20\% \\
7 & Istanbul University-Cerrahpasa Graduate Education Institute & below 20\% \\
8 & Istanbul Yeni Yuzyil University & below 20\% \\
9 & Mimar Sinan Guzel Sanatlar University Institute of Social Sciences & below 20\% \\
10 & ODTU Graduate School of Natural and Applied Sciences & below 20\% \\
11 & Sakarya University & below 20\% \\
12 & Ataturk University Institute of Educational Sciences & below 23\% \\
13 & Balikesir University Institute of Social Sciences & below 24\% \\
14 & Dicle University Institute of Social Sciences & below 24\% \\
15 & Firat University Institute of Educational Sciences & below 25\% \\
16 & Kilis 7 Aralik University & below 25\% \\
17 & Suleyman Demirel University & below 25\% \\
\hline
\end{tabular}




\begin{tabular}{clc}
\hline 18 & Yildiz teknik University & below $25 \%$ \\
19 & Abant Izzet Baysal University Institute of Social Sciences & below $30 \%$ \\
20 & Bingol University Institute of Social Sciences & below $30 \%$ \\
21 & Erciyes University Institute of Social Sciences & below $30 \%$ \\
22 & Eskisehir Teknik University Graduate Education Institute & below 30\% \\
23 & Inonu Institute of Educational Sciences & below 30\% \\
24 & Izmir Kâtip Celebi University & below 30\% \\
25 & Kayseri University & below 30\% \\
26 & KTU all institutes & below 30\% \\
27 & Marmara University Institute of Educational Sciences & below 30\% \\
28 & Mugla Sitki Kocman University Institute of Social Sciences & below 30\% \\
29 & Selcuk University Institute of Social Sciences & below 30\% \\
30 & TOBB University of Economics \& Technology Graduate School of Natural and Applied Sciences & below 30\% \\
31 & Trakya University Institute of Social Sciences & below $35 \%$ \\
\hline Mean & $\mathbf{2 4 , 7 0}$ \\
\hline
\end{tabular}

According to Table 2, the mean of an acceptable lower limit of similarity for some universities in Turkey is 24.70. This rate is compatible with the similarity classification of Turnitin program. Therefore, the classification of the findings was made according to the colour grouping of the Turnitin program, and the acceptable limit of similarity was considered 24 in this study. Similarity classification is shown in colours in the Turnitin program. This classification is as follows:

- Blue (no matching words)

- Green (1 - 24\% similarity rate)

- Yellow (25-49\% similarity rate)

- Orange (50-74\% similarity rate)

- $\operatorname{Red}(75-100 \%$ similarity rate) (Turnitin, 2020b).

These colorations were determined by the researchers as "Very high" for the percentage between $75 \%$ and $100 \%$, "High" for the percentage between $50 \%$ and $74 \%$, "Moderate" for the percentage between $25 \%$ and 49\%, "Low" for the percentage between $1 \%$ and $24 \%$, and "No Similarity" for $0 \%$. The similarity rates were shown in the findings section by being tabulated both in general and within the scope of the variables of the study (year of study, gender, university, and teaching field). The tables were interpreted and expressed separately.

\section{Qualitative Data Collection and Analysis}

Participants were divided into two groups as "those who plagiarized the most" and "those who plagiarized the least". A question pool was created to interview students. Based on the expert opinion, the semi-structured interview form took its final form. Each participant was called by phone and interviewed separately. The interviews were recorded with the consent of the participants. Then, they were transcribed and prepared for the analysis phase. Content analysis was used. Content analysis aims to reach the conceptual and relational meanings of the research subject based on the data (Creswell \& Poth, 2018; Yildirim \& Simsek, 2016). It has four comprehensive stages (Denzin \& Lincoln, 2008; Yildirim \& Simsek, 2016). These stages were carried out in the current study as follows: 
- Coding: Data were divided into two parts. Each part was given a researcher. First, data were read superficially. Second, data were re-read, and the first coding process was performed. Then, the third reading was made for consistency, and the main codes were created. In the next step, the parts were changed, and the steps mentioned above were repeated. Thus, the contents of each section were coded separately by the researchers. In the last stage of coding, the original codes of the researchers were brought together, compared and discussed, and the final codes were determined.

- Finding themes: Based on the codes obtained, themes and sub-themes were created. This stage was expressed by the researchers as a trial period to create themes.

- Arranging of codes and themes: Since the large number of themes and sub-themes causes information and meaning confusion, the codes were reviewed, and the themes and sub-themes were simplified.

- Identifying and interpreting the findings: After the qualitative data were analysed, findings were presented by combining qualitative and quantitative data at the last stage.

\section{FINDINGS}

This part includes quantitative and qualitative findings.

\section{Quantitative Findings}

Table 3 presents the general findings regarding the similarity rates determined in the homework prepared by the students.

Table 3. General similarity rates

\begin{tabular}{lllc}
\hline Similarity rate (\%) & Definition of Similarity & N & $\%$ \\
\hline between $75 \%$ and $100 \%$ & Very high & 117 & 33.52 \\
between $50 \%$ and $74 \%$ & High & 62 & 17.77 \\
between $25 \%$ and $49 \%$ & Moderate & 62 & 17.77 \\
between $1 \%$ and $24 \%$ & Low & 69 & 19.77 \\
$0 \%$ & No similarity & 39 & 11.17 \\
\hline
\end{tabular}

N: Number of students

** Columns painted with this color presents the data of the homework that fit the lower limit of similarity (between $0 \%$ and $24 \%$ )

As is seen in Table 3, 117 students had a "Very High" similarity rate (between 75\% and 100\%). This represents $33.52 \%$ of the participants. Considering the "High" similarity rate (between 50\% and 74\%), there were 62 students. This represents $17.77 \%$ of the participants. Those who had a "Moderate" similarity rate (between $25 \%$ and $49 \%$ ) were 62 , representing $17.77 \%$ of the participants. Sixty-nine students had a "Low" similarity rate (between $1 \%$ and $24 \%$ ), which represents $19.77 \%$ of the participants. Finally, 33 students had no similarity, which makes $11.17 \%$ of the participants. While $30.94 \%$ of the students prepared homework in accordance with the specified (24\%) lower limit of similarity, $69.06 \%$ of them prepared homework with a similarity rate above this rate. Table 4 presents the similarity rates that students had according to year of study. 
Table 4. Similarity rates according to year of study

\begin{tabular}{|c|c|c|c|c|c|c|c|}
\hline \multirow{3}{*}{ Year of study } & \multicolumn{7}{|c|}{ Definition of Similarity } \\
\hline & & Very high & High & Moderate & Low & No similarity & \multirow{2}{*}{ Total } \\
\hline & & $\begin{array}{l}\text { between } 75 \% \\
\text { and } 100 \%\end{array}$ & $\begin{array}{l}\text { between } 50 \% \\
\text { and } 74 \%\end{array}$ & $\begin{array}{l}\text { between } 25 \% \\
\quad \text { and } 49 \%\end{array}$ & $\begin{array}{l}\text { between } 1 \% \\
\text { and } 24 \%\end{array}$ & $0 \%$ & \\
\hline \multirow{3}{*}{ 2nd } & $\mathrm{N}^{*}$ & 78 & 56 & 49 & 21 & 3 & 207 \\
\hline & $\%$ & 37.68 & 27.05 & 23.67 & 10.14 & 1.45 & 100 \\
\hline & \multicolumn{4}{|c|}{$\begin{array}{l}\text { Homework suitable for the lower limit of similarity } \\
\text { (between } 0 \% \text { and } 24 \% \text { is } \% \text {. }\end{array}$} & 10.14 & 1.45 & 11.59 \\
\hline \multirow{3}{*}{ 3th } & $\mathrm{N}$ & 39 & 6 & 13 & 47 & 37 & 142 \\
\hline & $\%$ & 27.46 & 4.23 & 9.15 & 33.1 & 26.06 & 100 \\
\hline & \multicolumn{4}{|c|}{$\begin{array}{l}\text { Homework suitable for the lower limit of similarity } \\
\text { (between } 0 \% \text { and } 24 \% \text { ) is } \% \text {. }\end{array}$} & 33.1 & 26.06 & 59.16 \\
\hline
\end{tabular}

\section{${ }^{*} N$ : Number of students}

** Columns painted with this color presents the data of the homework that fit the lower limit of similarity (between $0 \%$ and $24 \%$ )

Second-year students had a higher similarity rate compared to third-year students. While 78 second-year students had a similarity rate between $75 \%$ and $100 \%$, the number of third-year students was 39 . These rates represent $37.68 \%$ of second-year students and $27.46 \%$ of third-year students. While the number of second-year students having "High" similarity rate (between 50\% and 74\%) was 56, it was 6 for thirdyear students. These rates represent $27.05 \%$ of second-year students and $4.23 \%$ of third-year students. The number of second-year students who plagiarized between $25 \%$ and $49 \%$ was 49 , but it was 13 for thirdyear students. These rates represent $23.67 \%$ of second-year students and $9.15 \%$ of third-year students. Although 21 second-year students plagiarized between $1 \%$ and $24 \%$, this number was 47 for third-year students. These rates represent $10.14 \%$ of second-year students and $33.10 \%$ of third-year students. Only 3 second-year students didn't plagiarism, whereas this number was 37 for third-year students. These rates represent $1.45 \%$ of second-year students and $26.06 \%$ of third-year students. While $11.59 \%$ of the secondyear students prepared homework in accordance with the specified (24\%) lower limit of similarity, $88.41 \%$ of them prepared homework with a similarity rate above this rate. On the other hand, even though $59.16 \%$ of the second-year students prepared homework in accordance with the specified (24\%) lower limit of similarity, $-40.84 \%$ of them prepared homework with a similarity rate above this rate. Table 5 presents the similarity rates that students had according to gender.

Table 5. Similarity rates according to gender

\begin{tabular}{|c|c|c|c|c|c|c|c|}
\hline \multirow{3}{*}{ Gender } & \multicolumn{7}{|c|}{ Definition of Similarity } \\
\hline & & Very high & High & Moderate & Low & No similarity & Total \\
\hline & & $\begin{array}{l}\text { between } 75 \% \\
\text { and } 100 \%\end{array}$ & $\begin{array}{l}\text { between } 50 \% \\
\text { and } 74 \%\end{array}$ & $\begin{array}{l}\text { between } 25 \% \\
\text { and } 49 \%\end{array}$ & $\begin{array}{l}\text { between } 1 \% \\
\text { and } 24 \%\end{array}$ & $0 \%$ & \\
\hline \multirow{3}{*}{ Female } & $\mathrm{N}^{*}$ & 55 & 40 & 44 & 51 & 24 & 214 \\
\hline & $\%$ & 25.7 & 18.69 & 20.56 & 23.83 & 11.21 & 100 \\
\hline & \multicolumn{4}{|c|}{$\begin{array}{l}\text { Homework suitable for the lower limit of similarity } \\
\text { (between } 0 \% \text { and } 24 \% \text { ) is \%. }\end{array}$} & 23.83 & 11.21 & 35.04 \\
\hline \multirow{3}{*}{ Male } & $\mathrm{N}$ & 62 & 22 & 18 & 17 & 15 & 135 \\
\hline & $\%$ & 45.93 & 16.3 & 13.33 & 12.59 & 11.85 & 100 \\
\hline & \multicolumn{4}{|c|}{$\begin{array}{l}\text { Homework suitable for the lower limit of similarity } \\
\text { (between } 0 \% \text { and } 24 \% \text { ) is \%. }\end{array}$} & 12.59 & 11.85 & 24.44 \\
\hline
\end{tabular}

${ }^{*} N$ : Number of students

** Columns painted with this color presents the data of the homework that fit the lower limit of similarity (between $0 \%$ and $24 \%$ ) 
Considering gender, males had a higher similarity rate compared to females. While 55 females had a similarity rate between $75 \%$ and $100 \%$, the number of males was 39 . These rates represent $25.70 \%$ of females and $45.93 \%$ of males. While the number of females having a "High" similarity rate (between $50 \%$ and $74 \%$ ) was 40 , it was 22 for male students. These rates represent $18.69 \%$ of female students and $16.30 \%$ of male students. The number of female students who plagiarized between $25 \%$ and $49 \%$ was 44 , but it was 18 for male students. These rates represent $20.56 \%$ of female and $13.33 \%$ of male students. Although 51 female students plagiarized between $1 \%$ and $24 \%$, this number was 17 for male students. These rates represent $23.83 \%$ of female students and $12.59 \%$ of male students. While 24 female students didn't plagiarism, this number was 15 for male students. These rates represent $11.21 \%$ of female students and $11.85 \%$ of male students. While $35.04 \%$ of female students prepared homework in accordance with the specified (24\%) lower limit of similarity, $64.96 \%$ of them prepared homework with a similarity rate above this rate. On the other hand, even though $24.44 \%$ of male students prepared homework in accordance with the specified (24\%) lower limit of similarity, $75.56 \%$ of them prepared homework with a similarity rate above this rate. Table 6 presents the similarity rates that students had according to universities.

Table 6. Similarity rates according to universities in different geographical regions

\begin{tabular}{|c|c|c|c|c|c|c|c|}
\hline \multirow{3}{*}{ Teaching field } & \multicolumn{7}{|c|}{ Definition of Similarity } \\
\hline & & Very high & High & Moderate & Low & No similarity & \multirow{2}{*}{ Tota } \\
\hline & & $\begin{array}{l}\text { between } 75 \% \\
\text { and } 100 \%\end{array}$ & $\begin{array}{l}\text { between } 50 \% \\
\text { and } 74 \%\end{array}$ & $\begin{array}{l}\text { between } 25 \% \\
\text { and } 49 \%\end{array}$ & $\begin{array}{l}\text { between } 1 \% \\
\text { and } 24 \%\end{array}$ & $0 \%$ & \\
\hline \multirow{3}{*}{$\begin{array}{l}\text { Eastern Anatolia } \\
\text { Region X } \\
\text { University }\end{array}$} & $\mathrm{N}^{*}$ & 109 & 57 & 41 & 13 & 2 & 222 \\
\hline & $\%$ & 49.10 & 25.68 & 18.47 & 5.86 & 0.90 & 100 \\
\hline & \multicolumn{4}{|c|}{$\begin{array}{l}\text { Homework suitable for the lower limit of similarity } \\
\text { (between } 0 \% \text { and } 24 \% \text { ) is \%. }\end{array}$} & 5,86 & 0,90 & 6.76 \\
\hline \multirow{3}{*}{$\begin{array}{l}\text { South-eastern } \\
\text { Anatolia Region Y } \\
\text { University }\end{array}$} & $\mathrm{N}$ & 8 & 5 & 21 & 56 & 37 & 127 \\
\hline & $\%$ & 6.30 & 3.94 & 16.54 & 44.09 & 29.13 & 100 \\
\hline & \multicolumn{4}{|c|}{$\begin{array}{l}\text { Homework suitable for the lower limit of similarity } \\
\text { (between } 0 \% \text { and } 24 \% \text { ) is \%. }\end{array}$} & 44,09 & 29.13 & 73.22 \\
\hline
\end{tabular}

${ }^{*} N$ : Number of students

** Columns painted with this color presents the data of the homework that fit the lower limit of similarity (between $0 \%$ and $24 \%$ )

While $6.76 \%$ of the students studying at the University X in the Eastern Anatolia Region prepared homework in accordance with the determined (24\%) lower limit of similarity, $93.24 \%$ of them prepared homework with a similarity rate above this rate. Although $73.22 \%$ of the students studying at University $Y$ in the South-eastern Anatolian Region prepared homework in accordance with the determined (24\%) lower limit of similarity, $26.78 \%$ of them prepared homework with a similarity rate above this rate. Table 7 presents the similarity rates that students had according to teaching field. 
Table 7. Similarity rates according to teaching field

\begin{tabular}{|c|c|c|c|c|c|c|c|}
\hline & \multicolumn{7}{|c|}{ Definition of Similarity } \\
\hline \multicolumn{2}{|c|}{ Teaching field } & Very high & High & Moderate & Low & No similarity & \multirow{2}{*}{ Total } \\
\hline & & $\begin{array}{l}\text { between } 75 \% \\
\text { and } 100 \%\end{array}$ & $\begin{array}{l}\text { between } 50 \% \\
\text { and } 74 \%\end{array}$ & $\begin{array}{l}\text { between } 25 \% \\
\text { and } 49 \%\end{array}$ & $\begin{array}{l}\text { between } 1 \% \\
\text { and } 24 \%\end{array}$ & $0 \%$ & \\
\hline \multirow{3}{*}{$\begin{array}{l}\text { Pre-School } \\
\text { Teaching }\end{array}$} & $N^{*}$ & 0 & 1 & 3 & 13 & 7 & 24 \\
\hline & $\%$ & 0.00 & 4.17 & 12.50 & 54.17 & 29.17 & 100 \\
\hline & \multicolumn{4}{|c|}{$\begin{array}{l}\text { Homework suitable for the lower limit of similarity } \\
\text { (between } 0 \% \text { and } 24 \% \text { ) is } \% \text {. }\end{array}$} & 54.17 & 29.17 & 83.34 \\
\hline \multirow{3}{*}{$\begin{array}{l}\text { Turkish } \\
\text { Language } \\
\text { Teaching }\end{array}$} & $\mathrm{N}$ & 9 & 15 & 11 & 17 & 23 & 75 \\
\hline & $\%$ & 12 & 20 & 14.67 & 22.67 & 30.67 & 100 \\
\hline & \multicolumn{4}{|c|}{$\begin{array}{l}\text { Homework suitable for the lower limit of similarity } \\
\text { (between } 0 \% \text { and } 24 \% \text { ) is } \% \text {. }\end{array}$} & 22.67 & 30.67 & 53.34 \\
\hline \multirow{3}{*}{$\begin{array}{l}\text { Primary School } \\
\text { Teaching }\end{array}$} & $\mathrm{N}$ & 35 & 17 & 13 & 18 & 7 & 90 \\
\hline & $\%$ & 38,89 & 18,89 & 14,44 & 20 & 7.78 & 100 \\
\hline & \multicolumn{4}{|c|}{$\begin{array}{l}\text { Homework suitable for the lower limit of similarity } \\
\text { (between } 0 \% \text { and } 24 \% \text { ) is } \% \text {. }\end{array}$} & 20 & 7.78 & 27.78 \\
\hline \multirow{3}{*}{$\begin{array}{l}\text { Social Sciences } \\
\text { Teaching }\end{array}$} & $\mathrm{N}$ & 39 & 5 & 11 & 11 & 1 & 67 \\
\hline & $\%$ & 58.21 & 7.46 & 16.42 & 16.42 & 1.49 & 100 \\
\hline & \multicolumn{4}{|c|}{$\begin{array}{l}\text { Homework suitable for the lower limit of similarity } \\
\text { (between } 0 \% \text { and } 24 \% \text { ) is \%. }\end{array}$} & 16.42 & 1.49 & 17.91 \\
\hline \multirow{3}{*}{$\begin{array}{l}\text { Mathematics } \\
\text { Teaching }\end{array}$} & $\mathrm{N}$ & 17 & 12 & 8 & 4 & 2 & 43 \\
\hline & $\%$ & 39.53 & 27.91 & 18.60 & 9.30 & 4.65 & 100 \\
\hline & \multicolumn{4}{|c|}{$\begin{array}{l}\text { Homework suitable for the lower limit of similarity } \\
\text { (between } 0 \% \text { and } 24 \% \text { ) is \%. }\end{array}$} & 9.30 & 4.65 & 13.95 \\
\hline \multirow{3}{*}{ Music Teaching } & $\mathrm{N}$ & 6 & 3 & 6 & 2 & 0 & 17 \\
\hline & $\%$ & 35.29 & 17.65 & 35.29 & 11.76 & 0.00 & 100 \\
\hline & \multicolumn{4}{|c|}{$\begin{array}{l}\text { Homework suitable for the lower limit of similarity } \\
\text { (between } 0 \% \text { and } 24 \% \text { ) is \%. }\end{array}$} & 11.76 & 0.00 & 11.76 \\
\hline \multirow{3}{*}{ Art Teaching } & $\mathrm{N}$ & 11 & 9 & 10 & 3 & 0 & 33 \\
\hline & $\%$ & 33.33 & 27.27 & 30.30 & 9.09 & 0.00 & 100 \\
\hline & \multicolumn{4}{|c|}{$\begin{array}{l}\text { Homework suitable for the lower limit of similarity } \\
\text { (between } 0 \% \text { and } 24 \% \text { ) is \%. }\end{array}$} & 9.09 & 0.00 & 9.09 \\
\hline
\end{tabular}

${ }^{*} N$ : Number of students

** Columns painted with this color presents the data of the homework that fit the lower limit of similarity (between $0 \%$ and $24 \%$ )

According to Table 7, while $83.34 \%$ of students studying at Preschool Teaching prepared homework suitable for the lower limit of similarity (24\%), $16.6 \%$ of them did not. While $53.34 \%$ of students studying at Turkish Language Teaching prepared homework suitable for the lower limit of similarity (24\%), $45.66 \%$ of them did not. While $27.78 \%$ of students studying at Primary School Teaching prepared homework suitable for the lower limit of similarity (24\%), $72.22 \%$ of them did not. While $17.91 \%$ of students studying at Social Science Teaching prepared homework suitable for the lower limit of similarity (24\%), 82,09\% of them did not. While $13.95 \%$ of students studying at Mathematics Teaching prepared homework suitable for the lower limit of similarity (24\%), $86.05 \%$ of them did not. While $11.76 \%$ of students studying at Music Teaching prepared homework suitable for the lower limit of similarity (24\%), 88.24\% of them did not. While $9.09 \%$ of students studying at Art Teaching prepared homework suitable for the lower limit of similarity (24\%), $90.91 \%$ of them did not. 


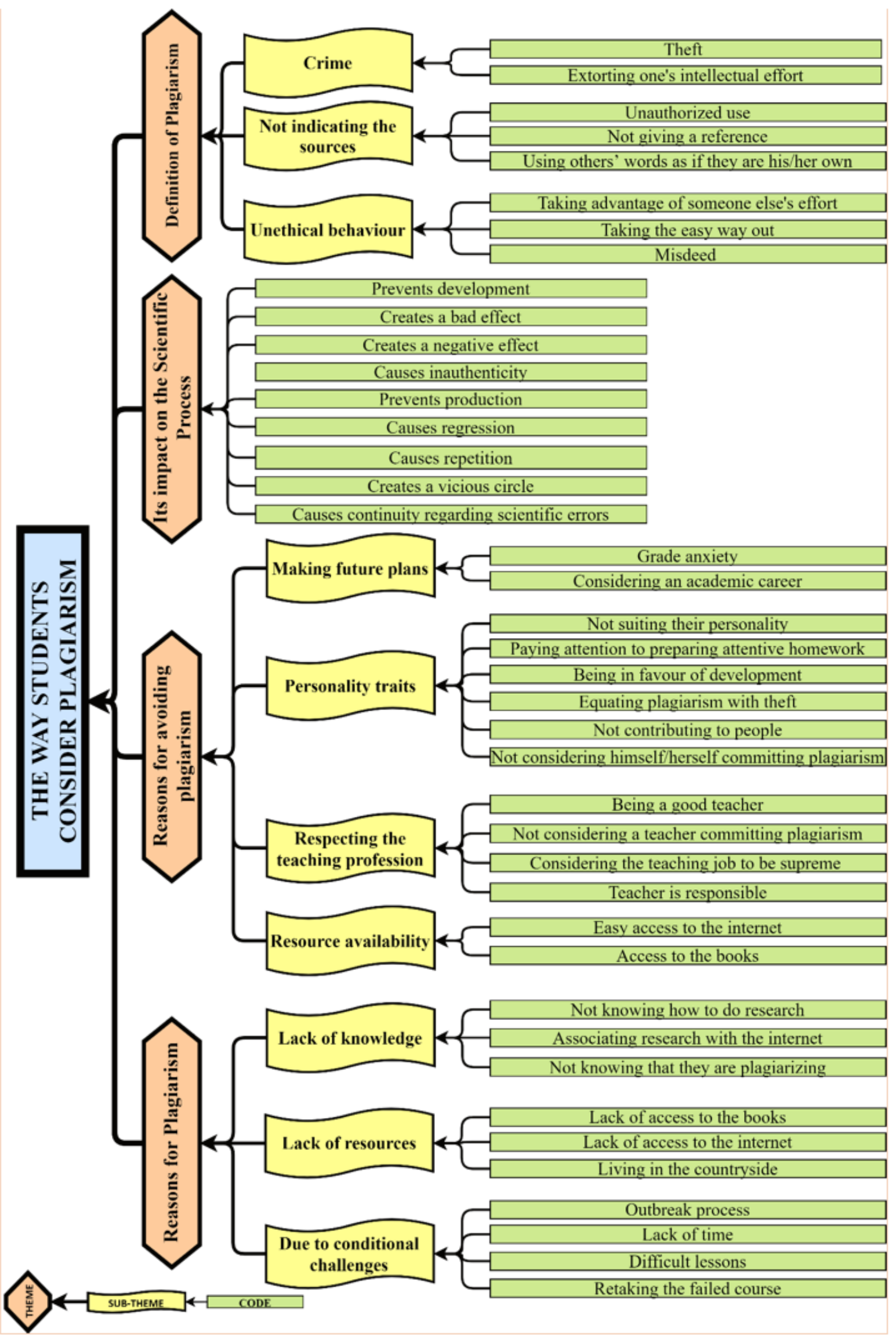

Figure 2. Theme, Sub-Theme, Code Map 


\section{Qualitative Findings}

The qualitative findings were grouped under four main headings: students' definitions of plagiarism, 2) students' views about how plagiarism affects the scientific process, 3) students' excuses for avoiding plagiarism, 4) students' excuses for plagiarizing.

An informative map was created to concretely reveal the connections between the code, sub-themes and themes created during the analysis process. Figure 2 presents the map.

\section{Students' Views on the Definition of Plagiarism}

Various definitions were made during the interviews. Students defined plagiarism with expressions such as theft, extorting one's intellectual effort, unauthorized use, not giving a reference, using others' words as if they are his/her own, taking advantage of someone else's effort, take the easy way out, misdeed. Table 8 presents the codes, sub-themes and themes determined for the students' definitions of plagiarism.

Table 8. Students' definitions of plagiarism

\begin{tabular}{|c|c|c|c|}
\hline Theme & Sub-Theme & Code & Participant* \\
\hline \multirow{8}{*}{ 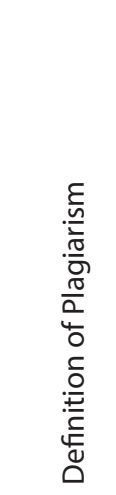 } & \multirow[t]{2}{*}{ Crime } & Theft & ST5, ST1, ST2, ST3, ST6, ST7, ST4 \\
\hline & & Extorting one's intellectual effort & ST7, \\
\hline & \multirow{3}{*}{ Not indicating the sources } & Unauthorized use & ST10, ST5, ST1, ST2, ST4 \\
\hline & & Not giving a reference & ST8, ST9, ST5, ST4, ST10, \\
\hline & & $\begin{array}{l}\text { Using others' words as if they are his/ } \\
\text { her own }\end{array}$ & ST9, \\
\hline & \multirow[t]{3}{*}{ Unethical behaviour } & $\begin{array}{l}\text { Taking advantage of someone else's } \\
\text { effort }\end{array}$ & ST6, \\
\hline & & Taking the easy way out & ST1, \\
\hline & & Misdeed & ST1, \\
\hline
\end{tabular}

*ST: Student teacher. Each student was codes as ST...

Table 8 shows three sub-themes under "Definition of Plagiarism": plagiarism, not indicating the sources, and unethical behaviour. The sub-theme of 'plagiarism' includes "theft" and "extorting one's intellectual effort". Students used some metaphors while defining plagiarism. For example, ST1 said "...plagiarism is theft." ST2 stated "... the definition of plagiarism is clear. It is research theft" On the other hand, ST7 defined plagiarism as extortion of one's intellectual effort, by saying "Man exists by what he does. Especially if he is doing research, he either gets help from someone or does it himself. Yet, he doesn't extort someone else's intellectual effort. This is plagiarism."

The sub-theme of 'not indicating the sources' involves "unauthorized use, not give reference, using others' words as if they are his/her own". ST1 explained that plagiarism was unauthorized use, stating that "... It is like using the work of someone else in scientific work without permission." ST2 expressed plagiarism as not to give reference: "... I think it is so, too. It is the use of one's work without his/her consent. It is a crime. This is what I know about plagiarism... If you want an academic definition, I personally say that plagiarism is using the information produced by someone else without permission." ST9 said, "...we all give a reference. If we don't, it is plagiarism. In sum, it is like using others' words as if they are his/her own. It is an act of copying and pasting."

Under the unethical behaviour sub-theme, "taking advantage of someone else's effort, taking the easy way out, and misdeed" are included. Here are some representative excerpts: ST6 said, "I can express my personal definition as taking advantage of someone else's effort." ST1 stated, "... I mean, if I want to explain plagiarism in my own words, I would describe it as a misdeed in research and homework." ST1 added that "...scientific researches are very hard work. That is why most people do not want to endure these diffculties, so they want to plagiarize and take the easy way out." 


\section{Students' Views about How Plagiarism Affects the Scientific Process}

According to teacher candidates, plagiarism "prevents scientific development, harms science, hurts scientific development, causes inauthenticity in science, prevents scientific production, causes scientific decline, causes a scientific repetition, creates a vicious circle in science, and causes continuity regarding scientific errors." These statements were determined as codes, and they were stated under the theme of "plagiarism in the scientific process". Table 9 presents the codes, sub-themes, and students.

Table 9. The themes and codes reached regarding the way plagiarism affects the scientific process

\begin{tabular}{|c|c|c|}
\hline Theme & Code & Participants* \\
\hline \multirow{9}{*}{ 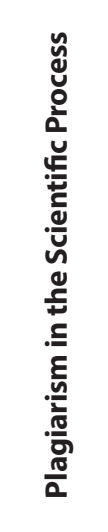 } & Prevents development & ST1, ST2, ST3, ST6, ST7, ST10 \\
\hline & Creates a bad effect & ST7, ST9, ST10, ST4 \\
\hline & Creates a negative effect & ST5, ST8, ST4 \\
\hline & Causes inauthenticity & ST5, ST4 \\
\hline & Prevents production & ST2, ST10 \\
\hline & Causes regression & ST1, ST3, \\
\hline & Causes repetition & ST1, ST4 \\
\hline & Creates a vicious circle & ST7 \\
\hline & Causes continuity regarding scientific errors & ST1 \\
\hline
\end{tabular}

*ST: Student teacher. Each student was codes as ST...

As is seen in Table 9, the theme of "plagiarism in the scientific process" consists of codes such as "prevents development, creates a bad effect, creates a negative effect, causes inauthenticity, prevents production, causes regression, causes repetition, creates a vicious circle, and causes continuity regarding scientific errors. The remarkable statements that determined the codes were stated below.

Some students stated that that plagiarism prevents development: “...plagiarism is something that prevents development" (ST1). "...plagiarism appears as something that hinders scientific development" (ST2). "... Plagiarism means that someone gains without working, trying, doing anything. I think everyone considers plagiarism as the biggest barrier to scientific development. I argue that everyone would give the same answer to this question." (ST6).

ST4 believed that plagiarism harmed the authenticity during the scientific process and used the following expressions: "... if you directly plagiarize, if you don't have your own knowledge and contribute to the work, it means that you don't have an authentic work." ST2 said that plagiarism prevents production: "... if everybody uses the same information, you will always circle around the same information. You can't produce anything new."

Some students drew attention to the fact that plagiarism would cause regression. For example, ST3 expressed this situation with the following statements: "... what could stealing improve so that it can improve. It only causes regression. ... plagiarism is stealing, it cannot develop. On the contrary, it may decline."

ST emphasized that that plagiarism caused regression during the scientific process: "...because new studies (that is, new information, new ideas, theories, etc.) are not carried out, it causes regression."

\section{Reasons for Avoiding Plagiarism}

The interviews indicated various reasons for avoiding plagiarism. Those who made low plagiarism listed their excuses, such as grade anxiety, considering an academic career, not suiting their personality, paying attention to preparing attentive homework, being in favour of development, equating plagiarism with theft, not contributing to people, not considering himself/herself committing plagiarism, being a good teacher, not considering a teacher committing plagiarism, considering the teaching job to be supreme, the thought that the teacher should be responsible, easy access to the internet, and having the opportunity to access the books. The aforementioned reasons were presented in table 10 . 
Table 10. Themes, sub-themes and codes determined for students' reasons for avoiding plagiarism

\begin{tabular}{|c|c|c|c|}
\hline Theme & Sub-Theme & Code & Participants* \\
\hline \multirow{14}{*}{ 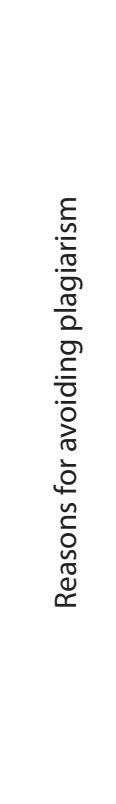 } & \multirow{2}{*}{ Making future plans } & Grade anxiety & ST10, ST8, ST9 \\
\hline & & Considering an academic career & ST7 \\
\hline & \multirow{6}{*}{ Personality traits } & Not suiting their personality & ST6, ST9 \\
\hline & & Paying attention to preparing attentive homework & ST10, ST8 \\
\hline & & Being in favour of development & ST7 \\
\hline & & Equating plagiarism with theft & ST9 \\
\hline & & Not contributing to people & ST9 \\
\hline & & Not considering himself/herself committing plagiarism & ST6 \\
\hline & \multirow{4}{*}{$\begin{array}{l}\text { Respecting the teaching } \\
\text { profession }\end{array}$} & Being a good teacher & ST7 \\
\hline & & Not considering a teacher committing plagiarism & ST7 \\
\hline & & Considering the teaching job to be supreme & ST6 \\
\hline & & Teacher is responsible & ST6 \\
\hline & \multirow{2}{*}{ Resource availability } & Easy access to the internet & ST6 \\
\hline & & Access to the books & ST6 \\
\hline
\end{tabular}

*ST: Student teacher. Each student was codes as ST...

As is seen in Table 10, the theme of "reasons for avoiding plagiarism" has four sub-themes: making future plans, personality trait, respecting the teaching profession, and resource availability.

"Making future planning" sub-theme has codes such as "grade anxiety" and "considering an academic career". Here are some representative excerpts:

ST10 stated that he avoided plagiarism for not getting poor marks: "...grade anxiety is one reason. I tried to obey the scientific rules, and I also avoid it due to grade anxiety. Because my goal was to get high scores." ST8 stated that "... there is no need to lie, I avoided for not getting low marks." Another participant (ST7) said that "... I am in favour of development. I want to develop myself. Maybe I will pursue an academic career in the future."

Under the "personality traits" sub-them, there are codes such as "not suiting their personality, paying attention to preparing attentive homework, being in favour of development, equating plagiarism with theft, not making a contribution to people, not considering himself/herself committing plagiarism." Some of the expressions that support the formation of these codes were as follows:

ST6, who said that plagiarism did not suit his personality, underlined that "... as I said, the plagiarism does not suit my personality." ST9 expressed that "... I am against plagiarism."

ST10, who said that he avoided plagiarism in order to prepare careful homework, said, “... I paid attention to both this task and my other homework. I stayed at home at that time. I had enough time. I cared about every task. I did not use to pay much attention before, but during this pandemic period, I did." ST9 emphasized as "I avoided plagiarism as much as possible. Copy-paste does not contribute to our development. I consider plagiarism as a thief. It is like stealing someone else's knowledge."

The "respecting the teaching profession" sub-theme included codes such as "being a good teacher, not considering a teacher committing plagiarism, considering the teaching job to be supreme, and teacher is responsible." Here are some excerpts:

ST6 avoided plagiarizing for such reasons: "... I find the teaching job supreme. I will also be a teacher. I will show my students the right way. That's why I didn't plagiarize."

ST7 argued that plagiarism does not suit teachers: "... Plagiarism causes trouble. Especially, teachers shouldn't plagiarize." ST6 stated, "... I said before. The person to be a teacher should be a responsible person." 
The "resource availability" sub-theme had codes such as "easy access to the internet and access to the books." It was created within the striking statements of ST6, who explained that he should stay away from plagiarism as he can easily access to the internet and the books: "... as a matter of fact, I used both the internet and the books. I have many books. I also benefited from various sources while using the internet. I didn't copy and paste from a single source. I gathered information from different sources."

\section{Reasons for Plagiarizing}

Students who made high plagiarism stated reasons such as "not knowing how to do research, associating research with the internet, not knowing that they are plagiarizing, lack of access to the books, lack of access to the internet, living in the countryside, the outbreak process, lack of time, the difficult lessons, and retaking the failed course." (please see Table 11).

Table 11. Themes, sub-themes and codes related to students' reasons for plagiarizing

\begin{tabular}{|c|c|c|c|}
\hline Theme & Sub-Theme & Code & Participants* \\
\hline \multirow{10}{*}{ 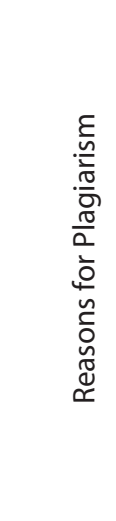 } & \multirow{3}{*}{ Lack of knowledge } & Not knowing how to do research & ST1 \\
\hline & & Associating research with the internet & ST1 \\
\hline & & Not knowing that they are plagiarizing & ST3 \\
\hline & \multirow{3}{*}{ Lack of resources } & Lack of access to the books & ST1, ST4 \\
\hline & & Lack of access to the internet & ST15 \\
\hline & & Living in the countryside & ST5 \\
\hline & \multirow{4}{*}{$\begin{array}{l}\text { Due to conditional } \\
\text { challenges }\end{array}$} & Outbreak process & ST2, ST4, ST5 \\
\hline & & Lack of time & ST2, ST5 \\
\hline & & Difficult lessons & ST2 \\
\hline & & Retaking the failed course & ST2 \\
\hline
\end{tabular}

*ST: Student teacher. Each student was codes as ST...

As is seen in Table 11, there are three sub-themes under the theme of "reasons for plagiarism": lack of knowledge, lack of resources, and due to conditional challenges.

"Lack of knowledge" has three codes: not knowing how to do research, associating research with the internet, and not knowing that they are plagiarizing. Here are some excerpts.

ST1 stated, "... actually, I could not learn how to research at school. It is necessary to know how to do research. However, we were not taught how to do it." Another reason uttered by ST1 was, "Students usually apply internet for doing research. They search on the internet and look for useful sites for the assignment given. Then, they find the necessary information there."

ST3 said that he did not know that what he did is plagiarism: "... sir, I did not know that I was plagiarizing. Now, after talking to you, I have just learned what plagiarism is. If you ask me to explain how I plagiarized, I cannot explain. I just used my smartphone and wrote down the assignments given to me. I copied what I saw and pasted it into Word. Then, I wrote my name and surname. Finally, I posted it."

The "lack of resources" sub-theme consisted of "lack of access to the books, lack of access to the internet, and living in the countryside." Some representative statements were as follows:

ST1 said, "... It's not good to come up with excuses for wrong actions. That's why I don't want to cover up my fault. We need a lot of books; we should go to the library." ST5 stated, "... as I said, I was busy with farming and lived in a village. I could not go to town. I had an internet problem in the village as well."

The sub-theme of "due to conditional challenges" had codes such as "outbreak process, lack of time, difficult lessons and retaking the failed course." Some statements were as follows: 
ST2 explained the reason for plagiarism as follows: "... I didn't have enough time. What would I have done if I hadn't made plagiarism? There is an outbreak." The same participant continued, "I retook many failed courses. I am still a third-year student. I have lessons of the first year. In fact, these shouldn't be counted as a reason for plagiarism, but as I said, it happened when a lot of lessons were accumulated. All of them are difficult lessons as well." ST5 said, "... when I learned the deadline, there were 2 days for the assignment. The process I went through, the deadline, and the outbreak were the reasons for plagiarism."

\section{DISCUSSIONS AND CONCLUSION}

This study examined the plagiarism rates of student students during the distance education process and investigated the reasons for plagiarising. Qualitative and quantitative findings were combined, and they were discussed within the scope of similar studies.

It was found that the majority did not prepare homework in accordance with the acceptable lower limit of similarity. This finding shows that most of the participants did not consider the level of similarity that would lead to plagiarism, one of the scientific ethical values. Pupovac et al. (2008), who investigated the plagiarism rates of university students in Spain, found similar findings. Ozden et al. (2015) conducted a study with students to examine the rates of plagiarism. They argued that half of the participants had committed plagiarism and/or cheating at least once during their university life. On the other hand, Kenny (2007) observed that most of the students studying in the nursing department plagiarized by copying and pasting and/or not providing references. In addition, some of the participants only benefited from internetbased resources without citing references. Literature abounds in similar studies investigating the issue of plagiarism. Some of these studies indicated that students plagiarized and/or cheated in scientific studies (Josephson Institute of Ethics, 2008; Mastin et al., 2009; Preiss et al., 2013; Mojeiko \& Rudkouski, 2019; Szabo \& Underwood 2004; Wood, 2004). Studies indicate that plagiarism rates have increased compared to previous years. There may be different reasons causing this increase. Some studies associate this situation with the development and spread of internet technology (Eret \& Gokmenoglu, 2010; Gullifer \& Tyson, 2010; Laird, 2001; Park, 2003; Power, 2009; Selwyn, 2008; Schmelkin et al., 2008; Szabo \& Underwood, 2004; Walker, 2010). According to the aforementioned studies, the internet enables students to easily copy and paste an assignment or alternatively download existing assignments and easily access most of the information they search (Chandrasoma et al., 2004; Dawson \& Overfield, 2006; Sutherland-Smith, 2008). The habits of today's students (such as downloading free music and movies as well as reading publications) cause students not to cite articles (Young, 2001). This situation increases even more when the generation that grows up using the internet extensively starts university (Kellogg, 2002). Thus, higher education institutions should convince their students to avoid using the resources accessed from the internet as if these works belong to them (Colon, 2001; Whiteneck, 2002). On the other hand, while the internet allows students to easily access and copy the materials, it also helps academicians to determine the plagiarism rates by comparing the texts (Park, 2003). Some studies argue that the increase in the rate of plagiarism is not related to the development and spread of internet technology, but rather to individual preferences (Howard, 2007; Marsh, 2007). Suggestions can be made to avoid plagiarism that was underlined in the literature. Academicians play important role in solving this problem. Considering Rezanejad and Rezaei (2013), 87.6\% of the university students stated that they learned the most concrete source about plagiarism from their instructors. On the other hand, most of the students (76.2\%) stated that they heard about plagiarism at the university for the first time. The results of this study showed that academicians could be effective in helping students gain an attitude towards plagiarism (Šprajc et al., 2017).

In this study, the plagiarism rates of the second-year students were higher than those of the third-year students. Almost all of the second-year students and half of the third-year students prepared homework in accordance with the determined lower limit of similarity. Therefore, the higher the class level was, the lower the rate of plagiarism was. Thus, the awareness of scientific ethics rules is directly proportionate to the class level. Stubbings and Brine (2003) support this finding. In their study, one of the reasons why undergraduate 
students plagiarized is that they did not know that plagiarism is wrong. In this context, they concluded that plagiarism was more common in first- and second-year classes compared to other classes. Similarly, Perry (2010) stated that $28 \%$ of the first-year students and $80 \%$ of the students studying in other classes believed that copy-paste was plagiarism. Hamilton (2003) found that while students' tendency to cheat and plagiarize is high in the first years of their university education, this rate decreases in the last year. Hrabak et al. (2004) reached similar results in their study. A study that supports this determination argued that upper-class university students were more knowledgeable and experienced about plagiarism awareness than lower-class students (Dawson \& Overfield, 2006). Considering this study, the difference in plagiarism rate between the grade levels may be due to the students' knowledge and experience. On the other hand, this difference in plagiarism rate between grade levels may also be related to the ages of the students. Thus, as the students' grade levels rise, their average age also increases. Studies in this context show that older students are less likely to cheat than younger ones (Christensen-Hughes \& McCabe, 2006; Finn \& Frone, 2004; McCabe \& Trevino, 1997; Newstead et al., 1996; Nonis \& Swift, 2001; Rakovski \& Levy, 2007; Vandehey et al., 2007). However, some studies (Ledesma, 2011; Seven \& Engin, 2008) found that senior students had higher levels of plagiarism than lower grade students. Besides, some studies (Eret \& Ok, 2014) stated that grade level was not significantly related to plagiarism.

According to the current study, male students plagiarize at a higher level than female students. This finding supports the literature. Bowers (1964) found that academic dishonesty in faculties was more common among men compared to women. Most of the studies support this finding (Jensen et al., 2002) reporting that women had lower copy rates than men (Aiken, 1991; Brown \& Choong, 2005; Davis et al., 1992; Smyth \& Davis, 2004; Ward, 1986; Whitley et al., 1999). Regarding gender, the aforementioned determination on cheating is in agreement with plagiarism. Selwyn (2008) found that male students plagiarized more than women. Various studies support this finding (Akbulut et al., 2008; Cetin, 2007; Eret \& Ok, 2014; Davis et al., 1992; Jereb et al., 2018; Ozgungor, 2008; Szabo \& Underwood, 2004). The reasons for this gender difference regarding plagiarism are that men take more risks than women, obey the rules less (Ersoy and Ozden 2011), perceive plagiarism as acceptable (Rawwas et al., 2004), have more problems referring to internet resources, believe that their academic studies will not benefit them (Šprajc et al., 2017), have a positive attitude towards plagiarism, believe that they will not be caught when they commit plagiarism, suppose that their gains are more than their losses, and think that their homework is not controlled (Jereb, et al., 2018). In addition, some studies did not support these results (indicating that women cheat more often than men) (Graham et al., 1994). On the other hand, some studies found no significant difference in cheating and plagiarism rates according to gender. As a matter of fact, in their experimental research on academic dishonesty, Crown and Spiller (1998) concluded that there was no significant difference in terms of gender in most of the studies published after 1982. Roig and Caso (2005) stated that there was no significant difference according to gender in terms of plagiarism rates. Studies argued that applying to academic dishonesty or plagiarism did not make a significant difference according to gender (Chapman et al., 2004; Hu \& Lei, 2015; Jordan, 2001; Jurdi et al., 2011; Pino \& Smith, 2003; Yardley et al., 2009).

Almost all of students of University X in the Eastern Anatolia Region and half of the students of University $\mathrm{Y}$ in the South-eastern Anatolia Region did not prepare their homework in accordance with the determined lower limit of similarity. Academicians who provided homework were not included in the study, but they were interviewed. While the academicians who were teaching at Y University in the Southeastern Anatolia Region frequently warned their students against plagiarism, the academics of X University in the Eastern Anatolia Region stated that they did not do anything. From this point of view, the difference between regions regarding the rate of plagiarism may be due to the attitudes of academicians towards plagiarism.

Considering the undergraduate departments, a few Pre-school Teaching undergraduate students prepared homework above the lower limit of similarity; Half of the Turkish Language Teaching students prepared homework above the lower limit of similarity; the majority of Primary School Teaching students prepared homework above the lower limit of similarity; Almost all of the Social Sciences Teaching, Mathematics Teaching, Music Teaching, and Art Teaching students prepared homework above the lower limit of 
similarity. A similar study was carried out by Ersoy and Karaduman (2010). In their study, Ersoy and Karaduman (2010) investigated plagiarism at the department level and found that 13\% of the reports prepared by Primary School Teaching students were plagiarized. Eraslan (2011) conducted a study with Mathematics Teaching students and observed that students had high plagiarism in the slides and reports they had prepared. According to Eret and Ok (2014), Mathematics Teaching students had a higher rate of internet-based plagiarism compared to Pre-School Teaching students. This finding is consistent with the results of this study. In their study carried out with of Social Sciences Teaching, Primary School Teaching, Pre-school Teaching, Turkish Language Teaching, and Science Teaching, Ozden et al., (2015) concluded that half of the participants applied for cheating and/or plagiarism at least once in their undergraduate life. The data obtained from the Social Studies and Primary Education Department students in the aforementioned study were compatible with the findings of the current study. However, the data of pre-school and Turkish Language Teaching students were not compatible with the findings of this study.

While defining the term, participants used "plagiarism, not indicating the sources, unethical behaviour." The codes of plagiarism were theft and extorting one's intellectual effort. The codes of not indicating the sources were unauthorized use, not giving references, and using others' words as if they are his/her own. The codes of unethical behaviour were using others' words as if they are his/her own, taking advantage of someone else's effort, taking the easy way out, and misdeed. Like this study, Rezanejad and Rezaei (2013) found that most of the participants considered plagiarism as copying and pasting without specifying the original source. They associated the reason for this definition with the dominant and common definition of the concept of plagiarism. On the other hand, in Benzer and Kara (2020), MA candidates defined plagiarism as "using someone else's data in your own work as it is; using someone else's idea or work as your own without acknowledging their work; and publishing without referring properly; scientific dishonesty and not following the rules when quoting a study." This confirms the findings of this study. Similar to the results of this study, in a study conducted with university students, Perry (2010) found that participants used metaphors to describe plagiarism. Perry (2010) stated that $24 \%$ of the participants thought that just copying word by word was plagiarism, while $23 \%$ of them thought that anything without quotations was plagiarism. In the present study, students were partially successful in identifying plagiarism. However, the quantitative data indicated that the students had made a high level of plagiarism. This determination shows that students do not act in accordance with the definitions of plagiarism. This coincides with the literature. Students can usually clearly state the definition of plagiarism. However, many of the students cannot act according to the definitions of plagiarism (Dawson \& Overfield 2006; Power, 2009).

Regarding the way plagiarism affects the scientific process, participants stated that plagiarism prevents scientific development, creates a bad and a negative effect, causes inauthenticity, prevents production, causes regression and repetition, creates a vicious circle, and causes continuity regarding scientific errors. The present study shares similar findings with Ennam (2017) who conducted a study with Moroccan university students and Benzer and Kara (2020) who examined Turkish MA candidates.

Participants listed the reasons for avoiding plagiarism as making future plans, not associating it with their personality traits, respecting the teaching profession, and the availability of academic resources. Participants expressed the making future plans with concepts such as grade anxiety and considering an academic career. They explained the personality trait with concepts such as not suiting their personality, paying attention to preparing attentive homework, being in favour of development, equating plagiarism with theft, not making a contribution to people, and not considering himself/herself committing plagiarism. For respecting the teaching profession, they used Being a good teacher, not considering a teacher committing plagiarism, considering the teaching job to be supreme, and teacher is responsible. They utilized easy access to the internet and access to the books to explain resource availability. In Stoner's (2004) study, reasons for avoiding plagiarism were grouped under two categories (stealing from someone else and harming the plagiarist). This finding overlaps with the results of this study.

The findings indicate that reasons for plagiarizing are as follows: not knowing what plagiarism is, lack of resources and time, taking many courses, and the outbreak process. Wood (2004), who investigated the 
reasons for the high plagiarism rates of students, found that students do not know whether their products such as homework and projects are within the scope of plagiarism. Wood (2004) also concluded that this situation is related to the internet culture in the next generation. According to Pupovac et al. (2008), one of the main reasons for plagiarism is that the homework prepared by students is not subjected to plagiarism programs. Thus, most of the students continue to commit plagiarism. Ozden et al. (2015) advocate that most of students plagiarize because they know that they would not be subject to any sanctions. Ersoy (2014) warns that students plagiarize because of their inadequate research skills and their haste due to poor time management. According to the research conducted by Ersoy and Ozden (2011), while nearly half of the participants believed that they could prepare an assignment by copying and pasting the same information from the internet, almost half of them (48.1\%) didn't agree with this idea. Researchers emphasized that this situation stems from ignorance about plagiarism. On the other hand, DeVoss and Rosati (2002) and Stubbings and Brine (2003) stated time pressure on students and financial insufficiency were among the reasons for plagiarizing. Various studies have revealed that plagiarism is due to a lack of knowledge (Gursoy and Yildiz 2016; Ma et al., 2007; Uzun et al., 2007; Nemati, 2016; Rezanejad \& Rezaei, 2013). This finding coincides with the results of this study. Also, this study argued that one of the reasons for why students plagiarized was lack of time. Supporting this determination, Yardley et al. (2009) stated that students' most common reason to cheat was the limited time perception. This is also compatible with the reasons for plagiarism. As a matter of fact, the students in the study of Eret and Ok (2014) indicated time pressure (deadline) among the reasons for plagiarism. Various studies found similar results (Bamford \& Sergiou, 2005; Devlin \& Gray, 2007; Ennam, 2017; Eret \& Franklyn-Stokes \& Newstead, 1995; Foltynek et al., 2014; Gokmenoglu, 2010; Park, 2003). In Rezanejad and Rezaei (2013), students listed the reasons for plagiarism in order of priority as follows: 1-easiness of plagiarism, 2- lack of training in universities on the issue of plagiarism, 3-lack of time, 4-more confidence and belief in the original text, 5- lack of attention from professors to term projects. Among these reasons, lack of training in universities on the issue of plagiarism and lack of time overlap with the findings of the present study to a great extent.

\section{SUGGESTIONS}

Plagiarism is one of the main barriers to the development of science. Plagiarism is an obvious ethical problem, but it also causes extensive problems in terms of scientific practice. In this study, the dimensions of plagiarism are discussed. The current study advocates that plagiarism is an academic problem and should be prevented. In this context, some suggestions were made. These suggestions are as follows:

- It was determined that pre-service teachers' rates of plagiarism were generally high. Therefore, it should be emphasized effectively at every stage of higher education that plagiarism is a crime.

- It was determined that as the grade level of the students increased, the rate of plagiarism decreased. This is because the higher-grade students who take courses on scientific ethics issues become sensitive to plagiarism. For this reason, it is possible to reduce the rate of plagiarism through courses starting from the first semester of education.

- Male students were found to plagiarize more than female students. In this context, special practical courses on scientific ethics can be taught to male students.

- The rates of plagiarism differed by region. This is because while some academics have anti-plagiarism attitudes, others are more relaxed. Thus, academicians in all universities can be encouraged to take preventive measures against plagiarism.

- The rates of plagiarism differed from department to department. This result is due to the fact that scientific ethics courses are taught at different grade levels in each department. Thus, scientific research and scientific ethics courses can be taught in each department from the first semester.

- Students were generally aware of the concept of plagiarism, but some of them considered plagiarism as the only way due to their circumstances. Thus, conditions can be created to help students access scientific resources in the distance education. Also, necessary equipment can be provided to the students who need it to actively participate in the distance education processes. 
- Courses for teaching scientific ethics should be taught comprehensively, and measurement-evaluation dimensions should be carefully designed.

- Academics should not tolerate plagiarism.

- If needed, technological tools should be used to prevent plagiarism.

- Academicians should carefully examine all products prepared by the student. If there is any plagiarism, students should be informed.

Studies have investigated plagiarism and provided suggestions in terms of preventing plagiarism. Uzbay (2016) emphasizes that those responsible for plagiarism are not only students but also those who allow this situation. According to Popyack et al. (2003), educators should focus on the definition of plagiarism and the sanctions for plagiarism in their courses. In addition, they should be closely interested in technology and benefit from various software. Many similar studies have provided recommendations for preventing plagiarism (Avarogullari, 2016; Council of Writing Program Administrators, 2008; Cetin, 2007; Dick et al., 2008; Ellery, 2008; James et al., 2002; Ma et al., 2008; Mojeiko and Rudkouski, 2019; Moon, 2005; Park, 2003; Power, 2009; TUBA Scientific Ethics Committee, 2002; Wilkinson, 2009).

Acknowledgements: Thanks to the people who participated in this research.

\section{BIODATA and CONTACT ADDRESSES of AUTHORS}

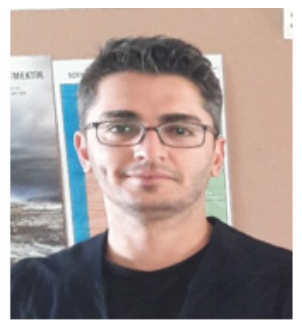

Dr. Huseyin BAYRAM received his Ph.D degree in Social Studies Education at Anadolu University in 2021. Currently, he is working as Assistant Professor in Social Studies Education at Faculty of Education of Agri Ibrahim Cecen University. His academic interests are social studies education, teacher education, learning models and research education. There are many numbers of published papers of his in various journals. And there are many numbers of presentations of his at different congresses.

\section{Huseyin BAYRAM}

Department of Social Studies Education, Faculty of Education

Address: Agri Ibrahim Cecen University, Faculty of Education, Department of Social Studies Ecucation, 04100, Agri, Turkey

Phone: +904722159863,

E-mail: hubayram@agri.edu.tr

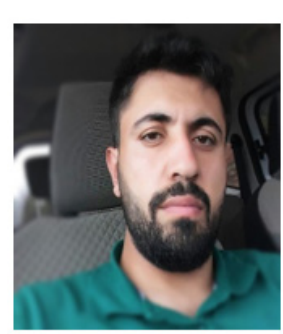

Fatih TIKMAN received his master degree in 2017 from the Institute of Educational Sciences, Social Studies Education at Gazi University. Then, he started Ph.D program at the Department of Social Studies Education at Anadolu University. Tikman is now working as a research assistant at social studies education department at Kilis 7 Aralik University. Of his research interests, Tikman focuses on Social Studies Education, teacher education, and Technological Pedagogical Content Knowledge. There are many numbers of published papers of his in various journals, and presentations at different congresses.

\section{Fatih TIKMAN}

Department of Social Studies Education, Faculty of Education

Address: Kilis 7 Aralik University, Muallim Rifat Faculty of Education, Department of Social Studies Ecucation, 79000, Kilis, Turkey

Phone: +903488142666,

E-mail: fatihtikman@kilis.edu.tr 


\section{REFERENCES}

Adam, L. (2016). Student Perspectives on Plagiarism. T. Bretag (Ed.), In Handbook of academic integrity (pp. 519-533). Springer.

Al Ahdab, S. (2020). Knowledge, attitudes and practices (KAP) towards pandemic COVID-19 among Syrians. BMC Public Health 21, 296 https://doi.org/10.21203/rs.3.rs-27859/v1

Ali, I. (2020). The COVID-19 Pandemic: Making sense of rumor and fear: Op-Ed. Medical Anthropology, 1-4. https://doi.org/10.1080/01459740.2020.1745481

Anderson, I. (2009). Avoiding plagiarism in academic writing. Nursing Standard (through 2013), 23(18), 35. https://doi.org/10.7748/ns.23.18.35.s51

Armstrong, M. B. (1993). Ethics and professionalism in accounting education: A sample course. Journal of Accounting Education, 11(1), 77-92. https://doi.org/10.1016/0748-5751(93)90019-f

Athabascau University, 2020. Doctor of Education in Distance Education. Retrieved October 20, 2020 from https://www.athabascau.ca/syllabi/edde/edde802.php

Avarogullari, M. (2016). Sosyal bilgiler ogretmen adaylarinin goruslerine gore intihalin sebepleri. Journal of Turkish Studies.11(3), 293-293. https://doi.org/10.7827/turkishstudies.9458

Bamford, J., \& Sergiou, K. (2005). International students and plagiarism: An analysis of the reasons for plagiarism among international foundation students. Investigations in University Teaching and Learning, 2(2), 17-22. Retrieved February 10, 2021 from http://repository.londonmet.ac.uk/173/

Batane, T. (2010). Turning to Turnitin to fight plagiarism among university students. Journal of Educational Technology \& Society, 13(2), 1-12. Retrieved February 02, 2021 from https://www.jstor.org/stable/ $\mathrm{pdf} /$ jeductechsoci.13.2.1.pdf

Bedford, J., Enria, D., Giesecke, J., Heymann, D. L., Ihekweazu, C., Kobinger, G., ... \& Ungchusak, K. (2020). COVID-19: towards controlling of a pandemic. The Lancet, 395(10229), 1015-1018. https://doi.org/10.1016/s0140-6736(20)30673-5

Benzer, S \& Kara, F. (2020) The determinants of the youth unemployment in graduate students' views on scientific research and publication ethics. Cankiri Karatekin University Journal of Institute of Social Sciences, 11(1), 288-308. Retrieved February 11, 2021 from http://web.b.ebscohost.com/ehost/ pdfviewer/pdfviewer?vid=0\&sid=f70f9e03-5c92-4b02-8392-596e91aa78e6\%40pdc-v-sessmgr06

Boon, H. (2011). Raising the bar: Ethics education for quality teachers. Australian Journal of Teacher Education, 36(7), 76-93. https://doi.org/10.14221/ajte.2011v36n7.2

Bryman, A. (2012). Social research methods. Oxford: Oxford University Press.

Buyukozturk, S. (2011). Handbook of data analysis for social sciences. Ankara: Pegem Academy Publishing.

Byrne, M. (2001). Sampling for qualitative research. AORN Journal, 73(2), 494-494. https://doi. org/10.1016/s0001-2092(06)61990-x

Chandrasinghe, P. C., Siriwardana, R. S., Kumarage, S. K., Gunathilake, B., Weerasuriya, A., Munasinghe, N. M., ... \& Fernando, R. F. (2020). Adapting surgical services at a tertiary care unit amidst the COVID19 pandemic: a Sri Lankan perspective. Sri Lanka Journal of Surgery, 38(1), 42-45. https://doi.org/10.4038/sljs.v38i1.8689

Chandrasoma, R., C. Thompson, and A. Pennycook. 2004. 'Beyond plagiarism: Transgressive and nontransgressive intertextuality. Journal of Language, Identity, and Education, 3(3), 171-93. https://doi.org/10.1207/s15327701jlie0303_1

Chapman, K. J., Davis, R., Toy, D. and Wright, L. (2004). Academic integrity in the business school environment: I'll get by with a little help from my friends. Journal of Marketing Education, 26(3), 236-249. https://doi.org/10.1177/0273475304268779

Colon, A. (2001). Avoid the pitfalls of plagiarism. Writer, 114(1), 8. [Google Scholar]

Coyne, I. T. (1997). Sampling in qualitative research. Purposeful and theoretical sampling; Merging or clear boundaries? Journal of Advanced Nursing, 26 (3), 623-630. https://doi. org/10.1046/j.1365-2648.1997.t01-25-00999.x 
Creswell, J. W., \& Plano-Clark, V. L. (2015). Karma yontem arastirmalari: Tasarimi ve yurutulmesi (Y. Dede \& S. B Demir, Trans. Eds.). Ankara: Ani Publishing.

Creswell, J. W., \& Poth, C. N. (2018). Qualitative inquiry and research design: Choosing among five approaches. Thousand Oaks CA: Sage.

Crown, D. F., \& Spiller, M. S. (1998). Learning from the literature on collegiate cheating: A review of empirical research. Journal of Business Ethics, 17(6), 683-700. https://doi.org/10.1023/a:1017903001888

Currie, P. (1998). Staying out of trouble: Apparent plagiarism and academic survival. Journal of Second Language Writing, 7(1), 1-18. https://doi.org/10.1016/s1060-3743(98)90003-0

Dant, D. R. (1986). Plagiarism in high school: A survey. The English Journal, 75(2), 81-84. https://doi. org/10.2307/817898

Davis, M. (1997). Developing and using cases to teach practical ethics. Teaching Philosophy, 20(4), 353-385. https://doi.org/10.5840/teachphil199720445

Dawson, M. M., \& Overfield, J. A. (2006). Plagiarism: Do students know what it is?. Bioscience Education, 8(1), 1-15. https://doi.org/10.3108/beej.8.1

Denzin, N. K., \& Lincoln, Y. S. (2008). Strategies of qualitative inquiry (Vol 2). Thousand Oaks, CA: Sage.

Department of Education, 2020. Initial teacher training (ITT): criteria and supporting advice. Retrieved October 25, 2020 from https://www.gov.uk/government/publications/initial-teacher-trainingcriteria/initial-teacher-training-itt-criteria-and-supporting-advice

Devlin, M., \& Gray, K. (2007). In their own words: A qualitative study of the reasons Australian University students plagiarize. High Education Research \& Development, 26(2), 181-198. https://doi. org/10.1080/07294360701310805

Doyle, L., Brady, A. M., \& Byrne, G. (2009). An overview of mixed methods research. Journal of Research in Nursing, 14(2), 175-185. https://doi.org/10.1177/1744987108093962

East, J. (2006). The problem of plagiarism in academic culture. International Journal for Educational Integrity, 2(2). https://doi.org/10.21913/ijei.v2i2.88

Ennam, A. (2017). Systematic analysis of the effects of digital plagiarism on scientific research: Investigating the Moroccan Context--Ibn Tofail University as case study. Journal of Education and Practice, 8(2), 133-141. Retrieved February 05, 2021 from https://eric.ed.gov/?id=EJ1131798

Eraslan, A. (2011). Prospective mathematics teachers and cheating: It is a lie if I say I have never cheated! Education \& Science, 36(160), 52-64. https://doi.org/10.47477/ubed.769597

Eret, E., \& Ok, A. (2014). Internet plagiarism in higher education: tendencies, triggering factors and reasons among teacher candidates. Assessment \& Evaluation in Higher Education, 39(8), $1002-$ 1016. https://doi.org/10.1080/02602938.2014.880776

Eret, E., \& T. Gokmenoglu, T. (2010). Plagiarism in Higher Education: A Case Study with Prospective Academicians. Procedia - Social and Behavioral Sciences, 2(2), 3303-3307. https://doi. org/10.1016/j.sbspro.2010.03.505

Ersoy, A. (2014). I was not aware I plagiarized from online resources: A phenomenological research. Journal of Education Faculty of Pamukkale University, 35(1), 47-60. https://doi.org/10.9779/puje654

Ersoy, A., \& Karaduman, H. (2010). Digital plagiarism in research reports prepared by prospective classroom teachers: Google search example. In 9th National Classroom Teachers Symposium Book. (p. 529534). Elazig: Firat University.

Ersoy, A., \& Ozden, M. (2011). The views of teacher candidates regarding the role of instructor in plagiarizing from Internet in their assignments. Ilkogretim Online, 10(2), 608-619. Retrieved February 10, 2021 from http://eds.a.ebscohost.com/eds/pdfviewer/pdfviewer?vid=0\&sid=8a6c3898-1 fd4437e-9a32-141a40a5bdd7\%40sessionmgr4007

Finn, K. V., \& Frone, M. R. (2004). Academic performance and cheating: Moderating role of school identification and self-efficacy. The journal of educational research, 97(3), 115-121. https://doi. org/10.3200/JOER.97.3.115-121 
Foltynek, T., Rybicka, J., \& Demoliou, C. (2014). Do students think what teachers think about plagiarism?. International Journal for Educational Integrity, 10(1). https://doi.org/10.21913/ijei. v10i1.931

Franklyn-Stokes, A., \& Newstead, S. E. (1995). Undergraduate cheating: who does what and why?. Studies in higher education, 20(2), 159-172. https://doi.org/10.1080/03075079512331381673

Gates, B. (2020). Responding to Covid-19-a once-in-a-century pandemic?. New England Journal of Medicine, 382(18), 1677-1679. https://doi.org/10.1056/nejmp2003762

George, M. (2010). Ethics and motivation in remedial mathematics education. Community College Review, 38(1), 82-92. https://doi.org/10.1177/0091552110373385

Graham, M.A., Monday, J., O’Brien, K. \& Steffen, S. (1994). Cheating at small colleges: An examination of student and faculty attitudes and behaviours. Journal of College Student Development, 35: 255. Retrieved February 09, 2021 from https://eric.ed.gov/?id=EJ489082

Gullifer, J., \& Tyson, G. A. (2010). Exploring university students' perceptions of plagiarism: A focus group study. Studies in Higher Education, 35(4), 463-481. https://doi.org/10.1080/03075070903096508

Guraya, S. Y., \& Guraya, S. S. (2017). The confounding factors leading to plagiarism in academic writing and some suggested remedies: A systematic review. The Journal of the Pakistan Medical Association, 67(5), 767-772. https://doi.org/10.12669/pjms.326.10490

Gursoy, A., \&Yildiz, O. (2016) Reasons of plagiarism based on views of social studies teacher candidates. Journal Turkish Studies. 11(3), 293-314. Retrieved February 06, 2021 from https://www.researchgate. net/profile/Muhammet_Avarogullari/publication/301343301_Sosyal_Bilgiler_Ogretmen_ Adaylarinin_Goruslerine_Gore_Intihalin_Sebepleri/links/5da087b645851553ff88bd11/SosyalBilgiler-Oegretmen-Adaylarinin-Goerueslerine-Goere-Intihalin-Sebepleri.pdf

Haas, A. (2005). Now is the time for ethics in education. The CPA Journal, 75(6), 66. Retrieved February 08, 2021 from https://search.proquest.com/docview/212287747?.pq-origsite=gscholar\&fromope nview=true

Hartnett, A. S., al-Natour, E., \& al-Ajlouni, L. (2020). Drastic Measures: Coercive enforcement and economic effects of pandemic suppression in Jordan. The COVID-19 Pandemic in the Middle East and North Africa, 65. https://doi.org/10.7189/jogh.10.020360

Hellewell, J., Abbott, S., Gimma, A., Bosse, N. I., Jarvis, C. I., Russell, T. W., ... \& Flasche, S. (2020). Feasibility of controlling COVID-19 outbreaks by isolation of cases and contacts. The Lancet Global Health, 8(4), 488-496.

Howard, R. M. (2007). Understanding "internet plagiarism". Computers and Composition, 24(1), 3-15. https://doi.org/10.1016/j.compcom.2006.12.005

Hrabak, M., Vujaklija, A., Vodopivec, I., Hren, D., Marušić, M., \& Marušić, A. (2004). Academic misconduct among medical students in a post-communist country. Medical Education, 38(3), 276-285. https://doi.org/10.1111/j.1365-2923.2004.01766.x

Hu, G., \& Lei, J. (2015). Chinese university students' perceptions of plagiarism. Ethics \& Behavior, 25(3), 233-255. https://doi.org/10.1080/10508422.2014.923313

Hughes, J. M. C., \& McCabe, D. L. (2006). Understanding academic misconduct. Canadian Journal of Higher Education, 36(1), 49-63. https://doi.org/10.47678/cjhe.v36i1.183525

Hwang, H. J., \& Youn, M. K. (2016). Based on proven practices in violation of research ethics for the KODISA Journals. The Journal of Industrial Distribution \& Business, 7(1), 5-10. https://doi. org/10.13106/ijidb.2016.vol7.no1.5.

Hwang, H. J., Lee, J. W., Kim, D. H., Shin, D. J., Kim, B. G., Kim, T. J., ... \& Youn, M. K. (2017). Cases of ethical violation in research publications: through editorial decision making process. The Journal of Distribution Science, 15(5), 49-52. https://doi.org/10.15722/jds.15.5.201705.49

Ilmiyah, S., \& Setiawan, A. R. (2020). Students' worksheet for distance learning based on scientific literacy in the topic coronavirus disease 2019 (COVID-19). https://doi.org/10.35542/osf.io/wyz5v 
Ivankova, N. V., \& Kawamura, Y. (2010). Emerging trends in the utilization of integrated designs in the social, behavioral, and health sciences. Sage Handbook of Mixed Methods in Social and Behavioral Research, 2, 581-611. https://doi.org/10.4135/9781506335193.n23

Jereb, E., Urh, M., Jerebic, J., \& Šprajc, P. (2018). Gender differences and the awareness of plagiarism in higher education. Social Psychology of Education, 21(2), 409-426. https://doi.org/10.1007/ s11218-017-9421-y

Johnson, R. B., \& Onwuegbuzie, A. J. (2004). Mixed methods research: A research paradigm whose time has come. Educational Rresearcher, 33(7), 14-26. https://doi.org/10.3102/0013189x033007014

Johnstone, A. H. (1991). Why is science difficult to learn? Things are seldom what they seem. Journal of Computer Assisted Learning, 7(2), 75-83. https://doi.org/10.1111/j.1365-2729.1991.tb00230.x

Jordan, A. E. (2001). College student cheating: The role of motivation, perceived norms, attitudes, and knowledge of institutional policy. Ethics \& Behaviour, 11, 233-247. http://dx.doi.org/10.1207/ S15327019EB1103_3

Jurdi, R., Hage, H. S., \& Chow, H. P. (2011). Academic dishonesty in the Canadian classroom: Behaviours of a sample of university students. Canadian Journal of Higher Education, 41(3), 1-35. https://doi. org/10.47678/cjhe.v41i3.2488

Karasar, N. (2018). Research method. Ankara: Nobel Publishing.

Kellogg, A. P. (2002). Students plagiarise online less than many think, a new study finds. Chronicle of Higher Education, 48(23). Retrieved February 08, 2021 from [Google Scholar]

Keskin, U. (2017). An evaluation of the origin of scientific ethics violations. Usak University Journal of Social Sciences, 10(4), 653-674. Retrieved February 07, 2021 from https://dergipark.org.tr/en/ $\mathrm{pub} / \mathrm{usaksosbil} /$ issue/33405/371741

Kohlberg, L., \& Mayer, R. (1972). Development as the aim of education. Harvard Educational Review, 42(4), 449-496. https://doi.org/10.17763/haer.42.4.kj6q8743r3j00j60

Laird, E. (2001). We all pay for Internet plagiarism. The Education Digest, 67(3), 56. Retrieved February 02, 2021 from [Google Scholar]

Lane, M. S., \& Schaupp, D. (1989). Ethics in education: A comparative study. Journal of Business Ethics, 8(12), 943-949. https://doi.org/10.1007/bf00383429

Ledesma, R. G. (2011). Academic dishonesty among undergraduate students in a Korean university. Research in World Economy, 2(2), 25-35. https://doi.org/10.5430/rwe.v2n2p25

LoCastro, V., \& Masuko, M. (2002). Plagiarism and academic writing of learners of English. HERMESJournal of Language and Communication in Business, (28), 11-38. https://doi.org/10.7146/hjlcb. v15i28.25665

Mahmood, K. R. (2009). Plagiarism, copyright violation, duplication, fabrication, false statements, breach of research and publication ethics. Indian Journal of Dermatology, Venereology, and Leprology, 75(2), 182. https://doi.org/10.4103/0378-6323.48668

Marsh, B. (2007). Plagiarism, alchemy and remedy in higher education. New York: State University of New York Press.

Maxwell, B., \& Schwimmer, M. (2016). Professional ethics education for future teachers: A narrative review of the scholarly writings. Journal of Moral Education, 45(3), 354-371. https://doi.org/10.1080/03 057240.2016 .1204271

McCabe, D. L., \& Trevino, L. K. (1997). Individual and contextual influences on academic dishonesty: A multicampus investigation. Research in Higher Education, 38(3), 379-396. https://doi. org/10.1023/a:1024954224675

MEB, 2020. General Competencies for Teaching Profession. Retrieved October 22, 2020 from http://oygm. meb.gov.tr/meb_iys_dosyalar/2017_12/11115355_YYRETMENLYK_MESLEYY_GENEL_ YETERLYKLERY.pdf

Miguel Roig \& Marissa Caso (2005) Lying and Cheating: Fraudulent Excuse Making, Cheating, and Plagiarism, The Journal of Psychology, 139(6), 485-494, https://doi.org/10.3200/JRLP.139.6.485494 
Mullen, C. A. (2020). Does modality matter? A comparison of aspiring leaders' learning online and face-toface. Journal of Further and Higher Education, 44(5), 670-688. https://doi.org/10.1080/030987 7x.2019.1576859

Nelson, R. R. (1959). The simple economics of basic scientific research. Journal of Political Economy, 67(3), 297-306. https://doi.org/10.1086/258177

Nemati, A. (2016). MA Students` Viewpoints about Academic Misconduct, its Reasons and Anti-plagiarism Policies and Procedures in Iran. Modern Journal of Language Teaching Methods, 6(2), 475-481. Retrieved February 06, 2021 from https://mjltm.org/article-1-61-en.pdf

Newstead, S. E., Franklyn-Stokes, A., \& Armstead, P. (1996). Individual differences in student cheating. Journal of Educational Psychology, 88(2), 229-241. https://doi.org/10.1037/0022-0663.88.2.229

Nicola, M., Alsafi, Z., Sohrabi, C., Kerwan, A., Al-Jabir, A., Iosifidis, C., ... \& Agha, R. (2020). The socioeconomic implications of the coronavirus and COVID-19 pandemic: A review. International Journal of Surgery, 78, 185-193. https://doi.org/10.1016/j.ijsu.2020.04.018

Nonis, S., \& Swift, C. O. (2001). An examination of the relationship between academic dishonesty and workplace dishonesty: A multicampus investigation. Journal of Education for Business, 77(2), 6977. https://doi.org/10.1080/08832320109599052

Park, C. (2003). In other (people's) words: Plagiarism by university students--literature and lessons. Assessment \& Evaluation in Higher Education, 28(5), 471-488. https://doi.org/10.1080/02602930301677

Pastor, C. K. (2020). Sentiment analysis on synchronous online delivery of instruction due to extreme community quarantine in the Philippines caused by Covid-19 Pandemic. Asian Journal of Multidisciplinary Studies, 3(1), 1-6. https://doi.org/10.2139/ssrn.3574385

Pecorari, D. (2008). Academic writing and plagiarism: A linguistic analysis. London: Bloomsbury Publishing.

Perry, B. (2010). Exploring academic misconduct: Some insights into student behaviour. Active Learning in Higher Education, 11, 97-108. https://doi.org/10.1177/1469787410365657

Phoneix University, 2020. Legal and Ethical Issues in Education. Retrieved October 20, 2020 from https:// www.phoenix.edu/courses/edl535.html

Pino, N. W. \& Smith, W. L. (2003). College students and academic dishonesty. College Student Journal, 37(4), 490-500. Retrieved February 14, 2021 from https://scholar.google.com/scholar?hl=tr\&as_sdt=0\%2 C5\&q=Pino\%2C+N.+W.\%2C+\%26+Smith \%2C+W.+L.+\%282003\%29.+College+students+an $\mathrm{d}+$ academic+dishonesty.+College+Student+Journal\%2C+37\%284\%29\%2C+490-500.\&btnG= $\mathrm{t}=0 \% 2 \mathrm{C} 5 \& \mathrm{q}=\mathrm{Pino} \% 2 \mathrm{C}+\mathrm{N} .+\mathrm{W} . \% 2 \mathrm{C}+\% 26+$ Smith\%2C+W.+L.+\%282003\%29.+College+stude nts+and+academic+dishonesty.+College+Student+Journal\%2C+37\%284\%29\%2C+490-500.\&b$\mathrm{tnG}=$

Pjetursson, B. E., \& Lang, N. P. (2008). Prosthetic treatment planning on the basis of scientific evidence. Journal of Oral Rehabilitation, 35, 72-79. https://doi.org/10.1111/j.1365-2842.2007.01824.x

Power, L. G. (2009). University students' perceptions of plagiarism. The Journal of Higher Education, 80(6), 643-662. https://doi.org/10.1353/jhe.0.0073

Pupovac, V., Bilic-Zulle, L., \& Petrovecki, M. (2008). On academic plagiarism in Europe. An analytical approach based on four studies. Digithum, 10, 13-19. https://doi.org/10.7238/d.v0i10.507

Rakovski, C. C., \& Levy, E. S. (2007). Academic dishonesty: Perceptions of business students. College Student Journal, 41(2), 466-482. Retrieved February 09, 2021 from https://go.gale.com/ps/ anonymous?id=GALE\%7CA163679018\&sid=googleScholar\&v=2.1\&it=r\&linkaccess=abs\&issn $=01463934 \& \mathrm{p}=\mathrm{AONE} \& \mathrm{sw}=\mathrm{w}$

Raoofi, A., Takian, A., Sari, A. A., Olyaeemanesh, A., Haghighi, H., \& Aarabi, M. (2020). COVID-19 pandemic and comparative health policy learning in Iran. Archives of Iranian Medicine, 23(4), 220-234. https://doi.org/10.34172/aim.2020.02

Rezanejad, A., \& Rezaei, S. (2013). Academic dishonesty at universities: The case of plagiarism among Iranian language students. Journal of Academic Ethics, 11(4), 275-295. https://doi.org/10.1007/ s10805-013-9193-8 
Schmelkin, L. P., Gilbert, K., Spencer, K. J., Pincus, H. S., \& Silva, R. (2008). A multidimensional scaling of college students' perceptions of academic dishonesty. The Journal of Higher Education, 79(5), 587-607. https://doi.org/10.1080/00221546.2008.11772118

Selwyn, N. (2008). 'Not necessarily a bad thing...': A study of online plagiarism amongst undergraduate students. Assessment \& Evaluation in Higher Education, 33(5), 465-479. https://doi. org/10.1080/02602930701563104

Sentleng, M. P., \& King, L. (2012). Plagiarism among undergraduate students in the faculty of applied science at a South African higher education institution. South African Journal of Libraries and Information Science, 78(1), 57-67. https://doi.org/10.7553/78-1-47

Sercemeli, M., \& Kurnaz, E. (2020). A research on students' perspectives to distance education and distance accounting education in the covid-19 pandemia period. International journal of Social Sciences Academic Researches, 4(1), 40-53. Retrieved February 11, 2021 from https://dergipark.org.tr/en/ pub/utsobilder/issue/55152/741358

Seven, M. A., and A. O. Engin. (2008). Faculty of education students' cheating felt needs and reasons. Journal of Ataturk University Social Sciences Institute 11(1), 111-136. Retrieved February 13, 2021 from https://dergipark.org.tr/tr/pub/ataunisosbil/issue/2821/38042

Sheperis, D. S., Ordway, A., \& Lamar, M. (2020). Legal and ethical challenges in online counselor education. Professional Counselor, 10(1), 106-119. https://doi.org/10.15241/dss.10.1.106

Shields, D. L. (2011). Character as the aim of education. Phi Delta Kappan, 92(8), 48-53. https://doi. org/10.1177/003172171109200810

Sinelnikov-Murylev, S. G. (2020). Prospects for the Higher Eeducation System's Development in the Pandemic. Monitoring of Russia's Economic Outlook. Moscow. IEP, (6), 15-19. Retrieved February 11, 2021 from https://papers.ssrn.com/sol3/papers.cfm?abstract_id=3584037

Sisti, D. A. (2007). How do high school students justify internet plagiarism?. Ethics \& Behavior, 17(3), 215231. https://doi.org/10.1080/10508420701519163

Smedley, A., Crawford, T., \& Cloete, L. (2015). An intervention aimed at reducing plagiarism in undergraduate nursing students. Nurse Education in Practice, 15(3), 168-173. https://doi. org/10.1016/j.nepr.2014.12.003

Smith, M., Ghazali, N., \& Minhad, S. F. N. (2007). Attitudes towards plagiarism among undergraduate accounting students: Malaysian evidence. Asian Review of Accounting, 15(2), 122-146. https://doi. org/10.1108/13217340710823350

Šprajc, P., Urh, M., Jerebic, J., Trivan, D., \& Jereb, E. (2017). Reasons for plagiarism in higher education. Organizacija, 50(1), 33-45. https://doi.org/10.1515/orga-2017-0002

Stockholm University, 2020. Introduction to Educational Research Methods. Retrieved October 22, 2020 from https://www.su.se/english/search-courses-and-programmes/pea464-1.447376

Stoner, M. (2004). Why students should avoid plagiarism: What students say. Retrieved February 06, 2021 from http://library.csus.edu/content2.asp\%3FpageID=354.html

Stubbings, R., \& Brine, A. (2003). Plagiarism and the role of the library. Library \& Information Update, 2(12), $42-44$.

Sutherland-Smith, W. (2008). Plagiarism, the Internet, and student learning: Improving academic integrity. Routledge.

Szabo, A., \& Underwood, J. (2004). Cybercheats: Is information and communication technology fuelling academic dishonesty? Active Learning in Higher Education, 5, 180-199. https://doi. org/10.1177/1469787404043815

Tashakkori, A., \& Teddlie, C. (2003). Issues and dilemmas in teaching research methods courses in social and behavioural sciences: US perspective. International Journal of Social Research Methodology, 6(1), 61-77. https://doi.org/10.1080/13645570305055

Thiroux, J. P., \& Krasemann, K. W. (2001). Ethics: Theory and practice. Upper Saddle River, NJ: Prentice Hall. 
Towne, L., \& Shavelson, R. J. (2002). Scientific research in education. New York: National Academy Press Publications Sales Office.

Turnitin. (2020a). Feedback-Studio-Students. Retrieved September 30, 2020 from https://help.turnitin. $\mathrm{com} / \mathrm{tr} /$ feedback-studio/ogrenciler/benzerlik-kontrolu.htm

Turnitin. (2020b) Retrieved September 2, 2020 from https://help.turnitin.com/feedback-studio/turnitinwebsite/student/the-similarity-report/similarity-score-ranges.htm

TUBA (2002). Ethics and problems in scientific researches. Retrieved October 30, 2020 from http://www. tuba.gov.tr/files/yayinlar/raporlar/Bilimsel\%20Aras\%CC\%A7t\%C4\%B1 rmada\%20Etik\%20 ve\%20Sorunlar\%C4\%B1son.pdf

U.S Department of Education, 2020. Teacher Education. Retrieved October 25, 2020 from https://www. ed.gov/category/subject/teacher-education

Ullah, F., Wang, J., Farhan, M., Jabbar, S., Wu, Z., \& Khalid, S. (2020). Plagiarism detection in students' programming assignments based on semantics: Multimedia e-learning based smart assessment methodology. Multimedia Tools and Applications, 79(13), 8581-8598. https://doi.org/10.1007/ s11042-018-5827-6

University of Southampton, 2020. Retrieved October 25, 2020 from https://www.southampton.ac.uk/ courses/modules/educ2055.page

Uzbay, T. (2006). Sciencetific research ethics. In 4th Periodical Publishing in Health Sciences. Ankara, Turkey, Ulakbim.

Uzun, E., Karakus, T., Kursun, E., \& Karaaslan, H. (2007). Plagiarism through the eyes of the students: Reasons and suggestions for solutions. In Academic Informatics '07 Kutahya.

Vandehey, M., Diekhoff, G., \& LaBeff, E. (2007). College cheating: A twenty-year follow-up and the addition of an honor code. Journal of College Student Development, 48(4), 468-480. https://doi. org/10.1353/csd.2007.0043

Vibha, A. N. P., Kamath, G. B., \& Pai, D. V. (2020). Keeping the Country Positive during the COVID 19 Pandemic: Evidence from India. Asian Journal of Psychiatry, 51(2020), 102118. https://doi. org/10.1016/j.ajp.2020.102118

Walker, J. (2010). Measuring plagiarism: Researching what students do, not what they say they do. Studies in Higher Education, 35(1), 41-59. https://doi.org/10.1080/03075070902912994

Warnick,B.R., \&Silverman,S.K.(2011).Aframeworkfor professionalethicscoursesinteachereducation.Journal of Teacher Education, 62(3), 273-285. https://doi.org/10.1177/0022487110398002

Whiteneck, P. (2002). What to do with a thought thief. Community College Week, 14(24), 4-7. Retrieved February 11, 2021 from [Google Scholar]

Wood, G. (2004). Academic original sin: Plagiarism, the internet, and librarians. Journal of Academic Librarianship, 30(3), 237-242. https://doi.org/10.1016/j.acalib.2004.02.011

World Health Organization. (2020). Clinical management of severe acute respiratory infection (SARI) when COVID-19 disease is suspected. In Terim Guidance, 13 March 2020.

Yardley, J., Rodríguez, M. D., Bates, S. C., \& Nelson, J. (2009). True confessions?: Alumni's retrospective reports on undergraduate cheating behaviors. Ethics \& Behavior, 19(1), 1-14. https://doi. org/10.1080/10508420802487096

Yeditepe University, 2020. Morals and Ethics in Education. Retrieved October 9, 2020 from https://egitim. yeditepe.edu.tr/tr/ilkogretim-matematik-ogretmenligi-programi/dersler/3251

Yildirim, A., \& Simsek, H. (2016). Qualitative research methods in social sciences. Ankara: Seckin Publishing.

Young, J. R. (2001). The cat-and-mouse game of plagiarism detection. Chronicle of Higher Education, 47(43). Retrieved February 08, 2021 from https://eric.ed.gov/?id=EJ631133 